\title{
A Contribution to our Knowledge of the Vascular System of the Genus Equisetum.
}

\author{
BY
}

KATE BARRATT, M.SC.

With Plates VI and VII and twenty-four Figures in the Text.

I N spite of the large amount of work already published on the subject of 1 the anatomy of Equisetum, of which an excellent chronological account has been given by Lady Isabel Browne (1), there still seems to be a considerable lack of agreement as to the nature and origin of the various parts of the vascular system. The presence or absence of centripetal wood is one of the most prominent of these questions. As a contribution towards the solution of some of these problems it was decided to undertake a more thorough investigation of the anatomy of the sporeling, and to bring together and amplify our information on the development of the vascular system.

Hofmeister (3), as long ago as $185^{2}$, included a brief reference to this subject in his account of the genus. He gave an excellent figure of a young sporeling at the stage when its first lateral shoot was developing, but he does not refer in detail to the nature of the vascular structure.

In I 899 Jeffrey (4) described the development of sporelings of Equisetum hiemale and E. limosum, but only dealt generally with the anatomy of the young plant.

It was hoped that a further investigation of the sporeling anatomy would throw light upon the following points:

I. The nature of the stelar anatomy of the primary axis.

2. The phylogeny of the internodal bundle, with special reference to the metaxylem.

3. The elucidation of the vascular system of the node, in relation to the internode and the question of secondary thickening.

\section{Methods.}

One of the reasons for the incompleteness of our knowledge of these plants in their young stages probably lies in the fact that the sporelings are very slender and fragile, and that previous investigations have been largely confined to the examination of microtome sections.

Although serial sections have been used in this investigation, another

[Annals of Botany, Vo1. XXXIV. No. CXXXIV. April, 1920.] 
method, described below, has been employed to determine the relations existing between integral parts of the vascular system.

The species which has been most carefully worked through is E. arvense, owing to the ease with which the spores of this species could be obtained and the young plants raised under cultivation. But sporelings of $E$. maximum and $E$. limosum have also been employed.

The spores were sown on light soil immediately after gathering and the pots were kept in a frame at the ordinary temperature out of doors.

The prothallia appeared in the course of two or three days after sowing and the first young sporophytes were visible two months later. The prothallia were carefully removed from the soil, washed and pickled in 75 per cent. spirit. An abundance of material was thus available.

Plants of different sizes, varying from those still buried within the prothallial lappets to those showing three or four shoots, were detached from their prothallia and treated for twenty-four hours with a solution of eau de Javelle in the cold. At the end of that time the whole sporelings were transparent and extremely fragile. They were then washed in water and stained with ammoniacal fuchsin.1

The material was allowed to remain in the staining fluid for 24 hours or longer; it was then washed with alcohol several times and during this process the red colour appeared in the lignified tissues. The specimens were then dehydrated, cleared with oil of cloves, and mounted in Canada balsam. For some purposes it was found convenient to mount the stained specimens in glycerine jelly or euparal, the lower refractive index rendering the cellulose walls of the parenchymatous cells more visible.

Thin slides were employed for mounting, so that when desired the specimens could be examined from either side.

The resuit of this treatment is to render the whole sporeling transparent, and the lignified tissue, being vividly stained, stands out as a complete internal skeleton; it was possible to follow the course not only of the vascular strands but of their individual components, and thus to correct or confirm conclusions drawn from the examination of serial sections. Since the fuchsin also stains cuticularized membranes, the characteristic bands on the radial walls of the endodermal cells appear as a connected network (Plate VII, Fig. I).

The same method of clearing and staining was applied to the apices and mature shoots of adult plants with equal success. Before clearing the material each apex or shoot was split longitudinally into two halves and so mounted that the interior of the stem was uppermost. These thick specimens were mounted in Canada balsam in cells constructed for the purpose.

1 This stain is prepared for use by adding 5 per cent. solution of basic fuchsin in alcohol to strong ammonia 0.880 , so long as the liquid remains colourless; refer Zimmerman, Botanical Microtechnique, $\$ 27 \mathrm{r}$. 


\section{External Morphology of the Young Plant of EQUISETUM ARVENSE.}

As already stated, the young plant of Equisetum appears above the level of the prothallus about eight weeks after the sowing of the spores.

The young sporophyte consists of a slender primary stem continued below as a thin elongated root. At the level of the prothallus the first node is found bearing two or three leaves, their bases fused into a sheath and their distal parts free. Just below the level of the first inode, one can make out the embryonical organ, the foot. It appears as a protuberance on one side of the axis. The primary stem continues to elongate until several nodes are formed, each with two or three leaves, the larger number being the more common. The number of nodes formed by the first shoot is very variable, depending largely upon the general strength and external conditions of the young plant (Pl. VI, Fig. I, $a-g$ ).

At a very early stage in the latter's development, a bud is formed which gives rise to the first branch. It appears below the first node on the side remote from the foot, pushing its way out below the leaf-sheath. Its position on the axis varies considerably, as may be seen by reference to P1. VI, Fig. 2, $a$ and $b$; sometimes it is situated at a considerable distance below the attachment of the leaves and sometimes almost at the node. This bud, on emerging from the primary axis, takes a sharp turn downwards before ultimately taking the upward course of an aerial stem. Before the young branch makes its way through the cortex of the primary axis, it gives rise to an adventitious root which immediately grows out into the soil.

Other lateral buds may be developed sparingly at the upper nodes of the primary stem, but these develop much later if at all.

The secondary axis in its turn gives rise to a lateral bud with its associated root, and this process may be repeated until normally three or four upright shoots have appeared. There is a tendency for the laterformed shoots to be longer and more robust, with a gradually increasing number of leaves at the nodes (Pl. VI, Fig. I, $a-g$ ). There is, however, no great regularity in this last respect, the second shoot showing generally three leaves, and the third and fourth exhibiting four leaves in a whorl.

According to Jeffrey (4) as many as 12 erect shoots are produced in $E$. hiemale before the first rhizome makes its appearance, but in these cultures of $E$. arvense the number of aerial shoots has never exceeded five and the majority show three. The fate of the later-formed branches is dependent upon the conditions under which the sporelings are reared. In the plants resulting from thinly-sown spores, three aerial shoots were generally formed, and the fourth and fifth were destined to be rhizomes. The latter elongate very quickly and grow horizontally through the soil, 
giving off aerial branches at nodes some distance away from the primary axis.

In the later-sown cultures there was a tendency for an earlier preparation for winter conditions. This is usually brought about by the formation of one or two tubers in the place of rhizomes (Pl: VI, Fig. I, e, $f$ ).

In these artificial cultures it is well to bear in mind that the degree of development of the young plants is largely dependent on the external conditions, and especially on the density of the culture. Plants closely crowded are correspondingly hampered and restricted in development.

All the young plants figured in Pl. VI, Fig. I, $a-g$, were taken from the same culture and were from prothallia of the same age.

It is clear that the result of this early development of branches is the formation of a sympodium which is constructed from the bases of the firstformed aerial shoots. A distinct subterranean region is thus formed compounded from the bases of the second, third, and fourth aerial shoots. We shall see that the vascular structure of this region differs very strikingly both from the axis of the aerial stem and from that of the ordinary rhizomes.

At the close of the first season's growth the young plants may show quite extensive branch systems. The primary and secondary axes generally die down early, and always before the end of the first season's growth.

\section{ANATOMy OF THE SPORELING.}

The primary root exhibits a simple diarch structure, each xylem strand being composed at first of a single series of tracheides. As the root approaches the region of the foot the xylem is increased by the addition of relatively wider but shorter tracheides with coarsely reticulate markings, strikingly different from the typical long spiral and annular elements of the root. The normal elongated elements thus give place to a more or less solid mass of short strongly thickened tracheides which are of the type so constantly met with in the nodal regions of the mature plant.

Text-fig. I illustrates a series of transverse sections taken through a sporeling which has already produced a second aerial axis. From these it will be seen that the stele enlarges as it passes from the root upwards, and that the increase of tissue is due to the addition to the xylem of both parenchymatous cells and tracheides. One or two parenchymatous elements are found towards the centre of the mass (Text-fig. I, C), but at this stage they are neither numerous enough nor sufficiently constant in position to constitute a pith.

Under a high magnification these tracheides often exhibit an unusual appearance when seen in transverse section; the walls bordering on parenchymatous cells are thin and unlignified, a condition which tends to over- 
emphasize the proportion of parenchyma present in the xylem (Pl. VI, Fig. 5). The explanation may be found by reference to similar elements in the cleared preparations. Here they are seen to be short wide tracheides tapering sharply at both ends, with an irregular open reticulum of thickening, very large pits being found on the walls bordering parenchymatous cells; hence when a transverse section traverses one of these pits the wall appears quite unthickened (PI. VI, Fig. 6).

At this level the first indication of the presence of the branch supply makes its appearance (Text-fig. I, E and F). A gap is noted on one side of the xylem mass and the parenchymatous elements towards the centre of the stele come into direct communication with the central well-developed pith of the lateral shoot. The xylem of the latter, where it joins on to the main axis, is arranged in an unbroken cylinder (Text-fig. I). As the series of sections is traced upwards the gap in the xylem cylinder is closed by the appearance of elements belonging to the upper part of the branch stele, thus leaving no lateral gap in the wood above the branch trace. Gradually the primary vascular axis contracts in width and the proportion of parenchyma in the pith is reduced until at the level of the leaf-traces it has returned to the condition obtaining prior to the origin of the branch, and ultimately a solid protostele is found (Text-fig. I, G-M).

The attachment of the leaf-traces is not accompanied by any disturbance in the arrangement of the vascular tissue. The number of leaf-traces present at this first node is variable, not always agreeing with that of subsequent nodes on the same shoot. There seems to be a general tendency for one at least of the three leaf-traces typically present to be either reduced to a very short strand or to be absent altogether. This reduced trace is usually that adjoining the foot, but sometimes it is the one on the side towards the first lateral shoot (Text-fig. 2). There is a very decided tendency for the three leaf-traces to join the stele at different levels and thus to have a spiral arrangement (Pl. VI, Fig. 4). This might suggest that the very pronounced whorled character of the phyllotaxis of the adult plant may not be in itself a primitive character although it has been long established.

The transition from the solid protostelic condition, just described, to that of the internode above is sudden, and is marked by the change from short wide reticulate tracheides to a few much elongated annular ones (Text-fig. I, M, N, and O).

As Vidal (6) and others have pointed out, the stem may be regarded as built up of a series of segments, each consisting of a node with an accompanying internode. This conception is certainly supported by the manner in which the vascular tissue develops. The internodal protoxylem strands are the first to differentiate, as Quéva (7) has shown from his study of transverse sections. The strands correspond in number with the leaves 
the genus, and has also been shown to occur in all the stems of Calamites; it may therefore be considered as a relatively primitive character, since it is common to both living and fossil representatives.

\section{Origin of the Secondary Axis.}

Provision for the first branching is made very early in the history of the primary shoot, even while the latter is still enclosed within the folds of the prothallus.

Hofmeister (3), in his classical account of Vascular Cryptogams, figures

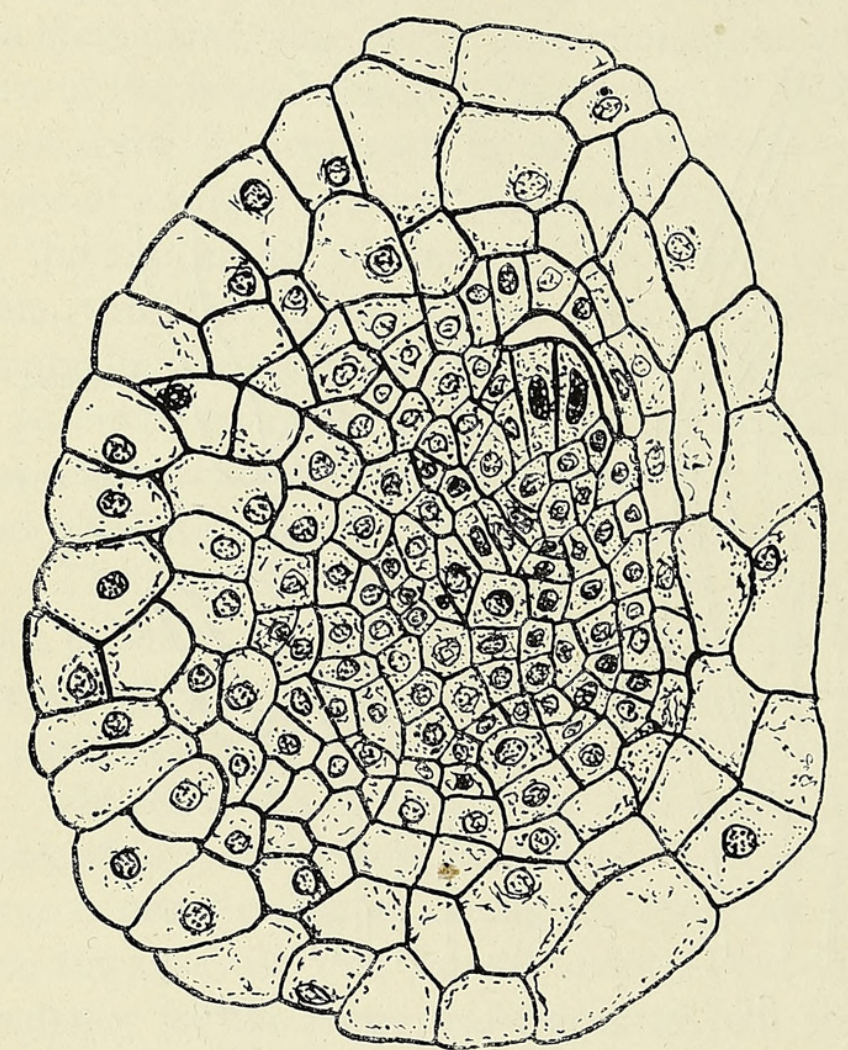

Text-Fig. 5. Transverse section from base of primary axis showing origin of the first bud. The apical cell is already established, although the xylem of the primary stem is not yet differentiated. $\times 95^{\circ}$. a young sporeling with the first lateral bud pushing its way through the tissues of the mother axis. He undoubtedly considered this bud to have an endogenous origin, but did not comment upon it in particular because at that time all the lateral buds of Equisetum were thought to arise from the central tissues.

It was later shown by Janczewski (8) and Vidal (6) that the whorled aerial branches take their origin from buds which arise from superficial cells of the stem at the base of the leaf-sheaths. It was consequently assumed that all the lateral buds arose in like manner.

Jeffrey (4), however, in his description of the sporeling, refers to its position low down on the axis well below the leaf-sheath, and speaks of it as the 'so-called adventitious bud', but does not make it clear whether this expression refers to its position on the axis or to its endogenous origin.

In order to determine the latter question, sporelings were sectioned in various directions. It was found that the bud initial is formed at a very early stage in the history of the primary shoot, in fact as soon as the first leaf-sheath is organized. From an examination of Text-fig. 5, one of a series of transverse sections, it is seen that the bud is undoubtedly endogenous and probably originates in the layer which gives rise to the endodermis. The young branch develops slowly and gradually pushes its 
Vascular System of the Genus Equisetum.

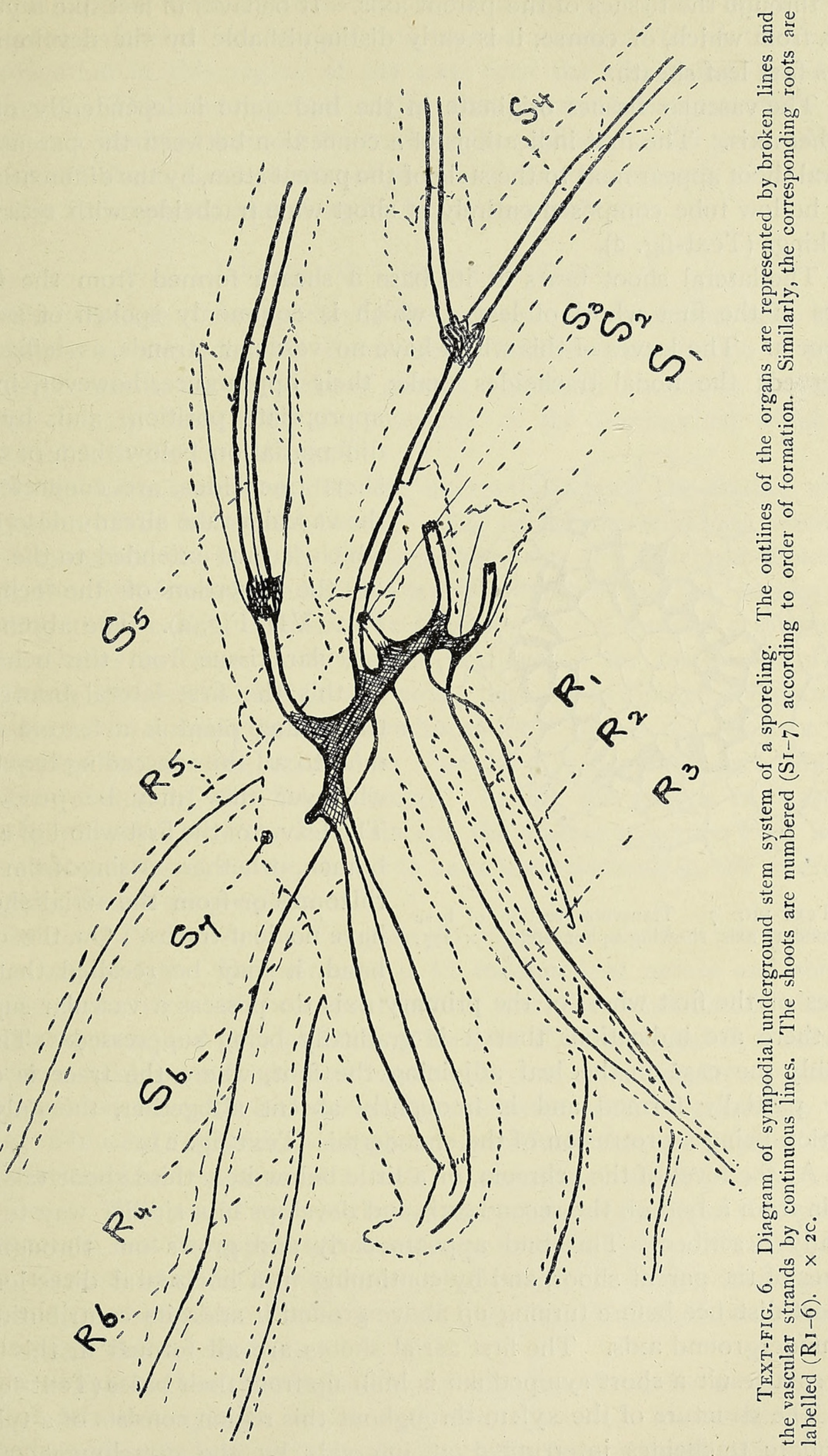


way through the tissues of the parent axis. It behaves in fact like a young root, from which, of course, it is early distinguishable by the development of its first leaf-sheath.

The vascular tissues originate in the bud quite independently of the mother axis. The first indications of a connexion between the parent and lateral shoot appear next to the stele of the parent stem, by the differentiation of a hollow tube composed entirely of short wide tracheides with reticulate markings (Text-fig. 2).

The lateral shoot bears at its base a sheath formed from the fused bases of the first whorl of leaves, which is commonly spoken of as the ochreola. The leaves of this whorl have no vascular strands, as Jeffrey (4) observed; the nodal tracheides make their appearance, however, in the appropriate position, and, by the

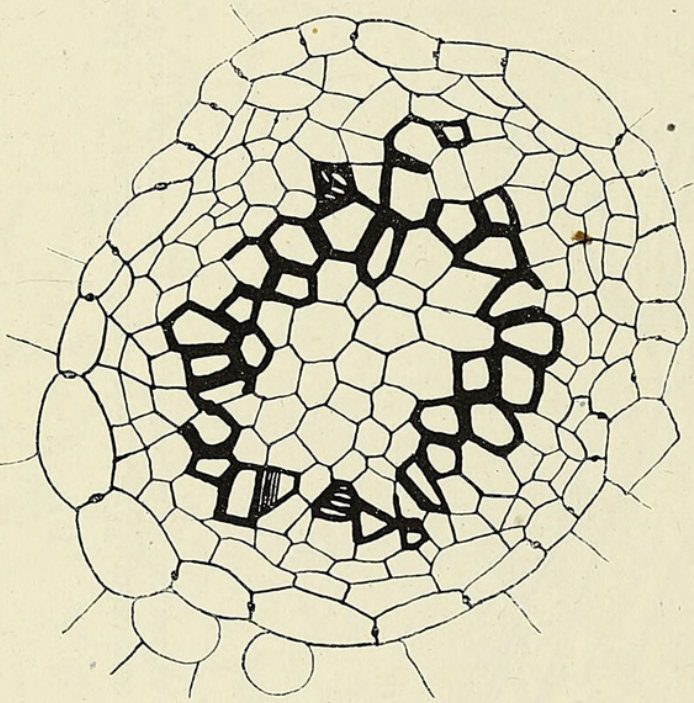

TEXT-FIG. 7. Transverse section of base of secondary axis, showing siphonostele. $\times 275$. differentiation below them of other short tracheides, are connected to the vascular tube already described, which is thus extended to the level of the insertion of the ochreola Plate VII, Fig. 2). The absence of vascular tissue from the ochreola of this the first lateral branch of the young plant is a feature common to all the succeeding branches, wherever they may be produced. The leaves of the first whorl of every branch, whether arising from the rhizomes or from the aerial shoots, have no leaf-traces. On the other hand, it may be recalled that the leaves of the first whorl of the primary axis do possess a vascular supply, but there are indications that it is gradually being suppressed. This is notably the case in the leaf adjoining the foot, where the trace is often only partially formed and is frequently absent altogether, the only indication being a protrusion of the endodermis (Text-fig. 2).

At the level of the ochreola, or a little below it, a third shoot takes its origin from a bud on the second axis and develops in a similar way to that already described. This bud appears early and grows out through the tissues of the parent shoot, and by continuing in a horizontal direction for a short distance before turning up above ground it adds its contribution to the underground axis. The first aerial shoots are all formed in this way, and as a result a short sympodium is built up from their bases (Text-fig. 6).

The structure of the xylem throughout this region consists of a tube of reticulate tracheides interrupted at intervals by the attachment of the 
vascular supplies from the aerial shoots (Text-fig. 7). There are no spiral and annular elements present, and this may be accounted for by the absence of elongation in this region of the axis once the conducting tissue has developed. This underground region thus presents features which only appear in a modified form at the bases of the ordinary aerial axes. As has been shown above, these structural peculiarities can be directly attributed to the early and repeated branching by which it is built up.

\section{ORIGiN OF THE METAXYLEM.}

The structure of the bundles in the internode of the mature stem is too well known to need detailed description. Of the three groups of xylem normally present, the two lateral groups, commonly known as the meta. xylem, develop later than the elements of the protoxylem which are associated with the carinal canal.

There have been two different interpretations of the nature of the metaxylem of the internodal bundle. The earlier investigators concluded that it comprised the laterally developed elements of a collateral bundle of which the first-formed elements were represented by the protoxylem adhering to the carinal canals. The similarity in the general arrangement of the tissues as seen in transverse sections of the internodes of any Equisetum compared with that of a young herbaceous dicotyledon naturally gave rise to the opinion that the structures were analogous. Such a type of structure is, however, unusual in Vascular Cryptogams apart from the well-known case of the Osmundaceae. In all the groups of Vascular Cryptogams other than the Equisetaceae the mature structure, even in the most elaborate types, can be shown to have been derived, in the course of ontogeny, from a simple protostele.

In I901 Prof. Gwynne-Vaughan (9) suggested another interpretation for the metaxylem. He pointed out its independent nature and showed that the protoxylem of the carinal canals was alone associated with the leaf-trace system, and he concluded, at least for E. hiemale and E. maximum, that the metaxylem strands were continuous over the nodes, merely altering their position laterally and becoming associated with neighbouring leaftraces. He went farther and suggested tentatively that this xylem might represent the last remnants of a mass of centripetal wood of a primitive protostele. This would involve the centripetal development of this portion of the wood, and he supported his theory by reference to E. giganteum, which showed what he interpreted as indications of such a development, but owing to the mature condition of all the available material he could not demonstrate this conclusively.

The question has thus definitely centred upon the order of differentiation of this metaxylem. Eames (10) and Quéva (7) have subsequently stated that the whole of the lateral metaxylem is centrifugal, although the 


\section{Barratt.-A Contribution to our Knowledge of the}

former records examples of certain irregularities in the direction of its lignification.

With regard to the elements composing this metaxylem, Quéva (7), from an examination of E. maximum and $E$. limosum, considers that they are all spirally thickened tracheides; but Eames (10) mentions that in E. maximum the elements of the lateral strands generally show sclariform, or reticulately pitted walls with occasional annular and spiral thickenings.

According to the results of the present investigation, there is no question that in $E$. arvense the majority of the tracheides composing this metaxylem are spirally thickened, the first developed ones being considerably drawn out during the later stages of elongation, and in some cases the elements break down, leaving small lacunae comparable to those associated with the protoxylem. On the other hand, in the later-formed elements it is seen that the thickening is more closely disposed until a simple form of reticulum results, requiring careful examination to distinguish it from the closer spiral forms.

This is found most elaborately developed in E. giganteum, and confirms Gwynne-Vaughan's observation that the smaller size of the outer elements suggested a centripetal order of development.

The order of differentiation of this particular region of the vascular system has been carefully traced both in the young sporeling and in the apices of adult shoots belonging to the following species: $E$. arvense and $E$. maximum: Although there is a variation in the amount of xylem developed, the order of its appearance is fairly constant.

The tissues which are destined to form these lateral xylem elements are early distinguishable as procambial strands. Elongation of the elements is almost completed in the internodes before any thickening takes place, although in some cases where growth has continued after the completion of the tracheides a certain amount of disruption occurs with the formation of small lateral lacunae. The thickening and lignification of the tracheides proceeds regularly through the internode; beginning in one cell which abuts upon the nodal tracheides, the process follows in the cells immediately below until a whole column is lignified (Text-fig. 8 and P1. VII, Fig. I). Before this is completed, however, another vertical row of cells begins to differentiate in the same way, and this scheme is followed until the whole group of tracheides is matured. Owing to the fact that the lignification does not take place simultaneously throughout the internode, it is possible to select one in which the material is in a half-developed condition. Some stem apices about two inches long were halved longitudinally, and one half of each apex was cleared with eau de Javelle and stained with fuchsin in the way already described. From these it could be ascertained which nodes showed the desired condition, and the companion halves were embedded in wax and microtomed. From the two sets of preparations it was possible to 
determine the order of differentiation of the elements in the lateral bundles.

It was thus clearly made out that the spiral and annular elements occur nearest to the carinal protoxylem, and that those subsequently differentiated occur nearer to the periphery of the stem and more remote from the canal.

The metaxylem strands of successive vegetative internodes are not directly continuous, but are linked together by means of the short, coarsely reticulate nodal tracheides, and no indication was found of any of these strands crossing the outer surface of the nodal xylem, as has been suggested by GwynneVaughan (9) for E. hiemale and $E$. maximum. The direct relation between the carinal protoxylem and the lateral metaxylem in the internode of the aerial shoots is not very clear owing to the separation in space and time between their respective developments. Further reference will be made to this, however, when the structure of the tubers and cones has been described.

In the course of an examination of some young vegetative axes of E. maximum, the large nodal tracheides described and figured by Sykes (11) were met with. They form quite early in the life of the shoot,

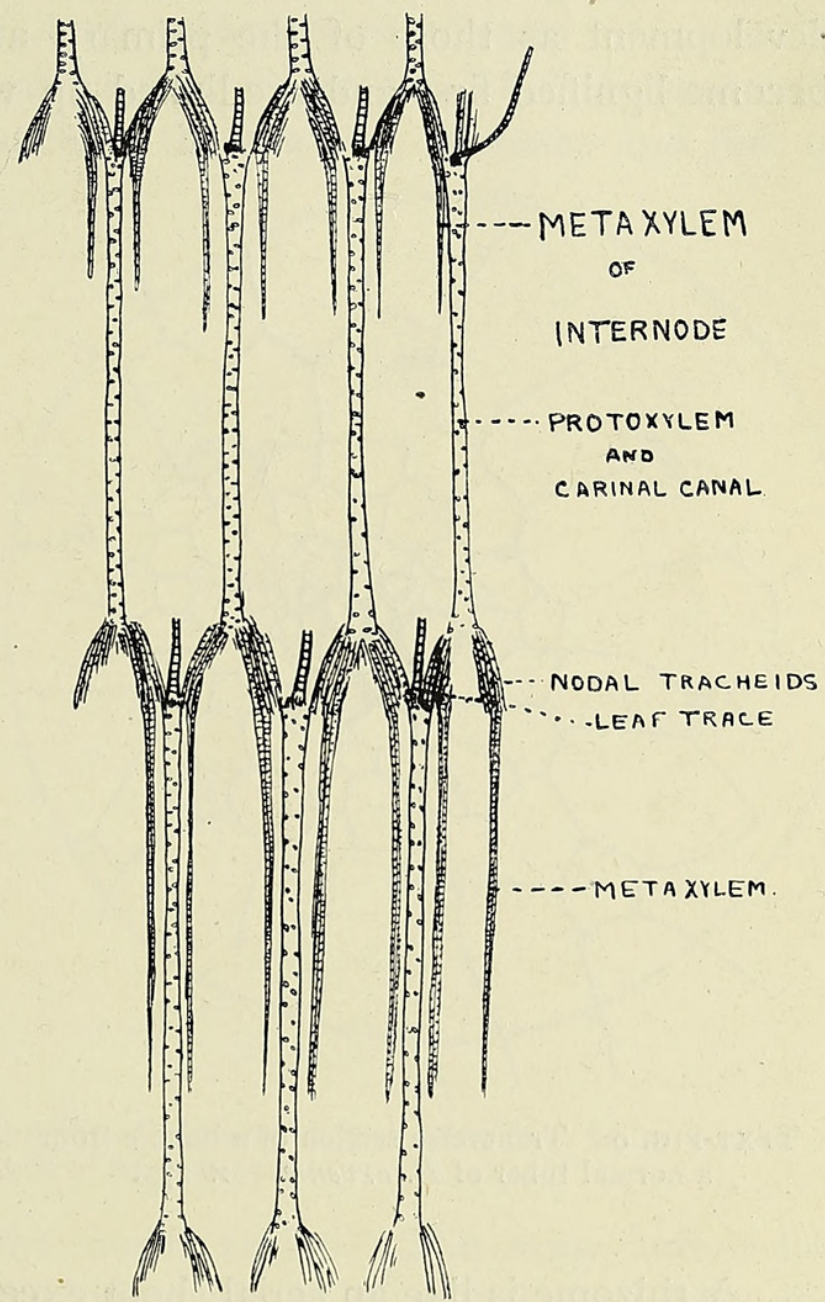

TeXT-FIG. 8. Diagram illustrating late development of the metaxylem. Length of internodes much reduced.

and are clearly ordinary nodal tracheides which owe their shape to the opportunity of free development afforded by their projection into the lumen of the canal. They are undoubtedly concerned with the transference of water from the carinal canals of one internode to those of the internode above, as Miss Sykes suggested. 


\section{ORIGIN OF LATERAL BUDS.}

The primary axis only gives rise sparingly to lateral buds, but as the successive aerial axes develop, they produce whorls of branches. These arise from buds which have been clearly demonstrated to be of exogenous origin $(6,8)$ and to occur in the axil of the leaf-sheaths, alternating in position with the leaf-teeth.

The tracheides of the bud internodes follow exactly the same order of development as those of the primary axis, i.e. the internodal elements become lignified first and are linked up with the leaf-traces and with the corresponding elements of

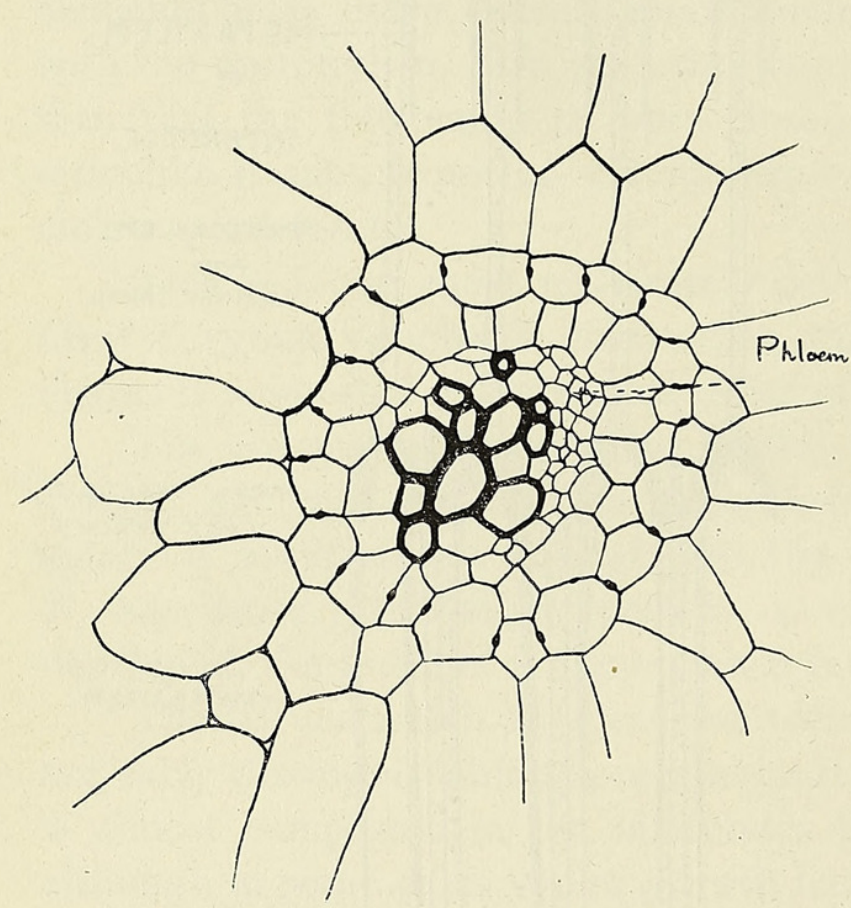

TEXT-FIG. 9. Transverse section of a bundle from a normal tuber of $E$. arvense. $\times 275$. higher internodes later by the short tracheides of the node.

The junction of the bud vascular system with that of the parent stem is brought about by the formation of a closed tube of short, strongly thickened elements repeating the structure already described which is found at the base of the secondary axis.

Rhizomes. The first rhizomes arise as lateral buds at the base of young aerial stems. In $E$. arvense they appear, as a rule, after three or four upright shoots have been formed, but this is dependent upon conditions of growth, as already stated.

A rhizome is like an aerial shoot except with regard to its direction of growth and its lack of chlorenchyma. Where the plants are left crowded together these rhizomes have not so good a chance of developing, and their growth may consequently be arrested. Towards the end of the summer other shoots grow out as short fat tubers (Pl. VI, Fig. I, $e, f)$. These tubers in the young plant consist only of one long swollen internode crowned by a small node and terminal bud, although in older plants a chain of tubers may be formed by the development of successive internodes.

There is a striking difference in structure between these two kinds of underground organs, both of which often grow out as lateral buds from the same axis at the same node, and apparently under the same conditions. The main difference in structure, apart from the great increase in paren- 
chyma, is a complete absence of air-channels in the tuber. In the tubers of the sporelings there are usually four bundles embedded in a great mass of starch-containing parenchyma. Each vascular strand is surrounded by a very evident endodermis, and in this respect the tuber of $E$. arvense differs from any of the other shoots of this species (Text-fig. 9).

Tubers which are formed on the rhizomes of mature plants vary considerably in form, as has been fully described by Duval-Jouve (12) and Milde (13). They may consist of single swollen internodes, or of a series similar to the well-known case of Arrhenatherum avenaceum.

In the more swollen tubers, as Leclerc du Sablon (14) has shown, the vascular strands branch before reaching the greatest diameter and link up

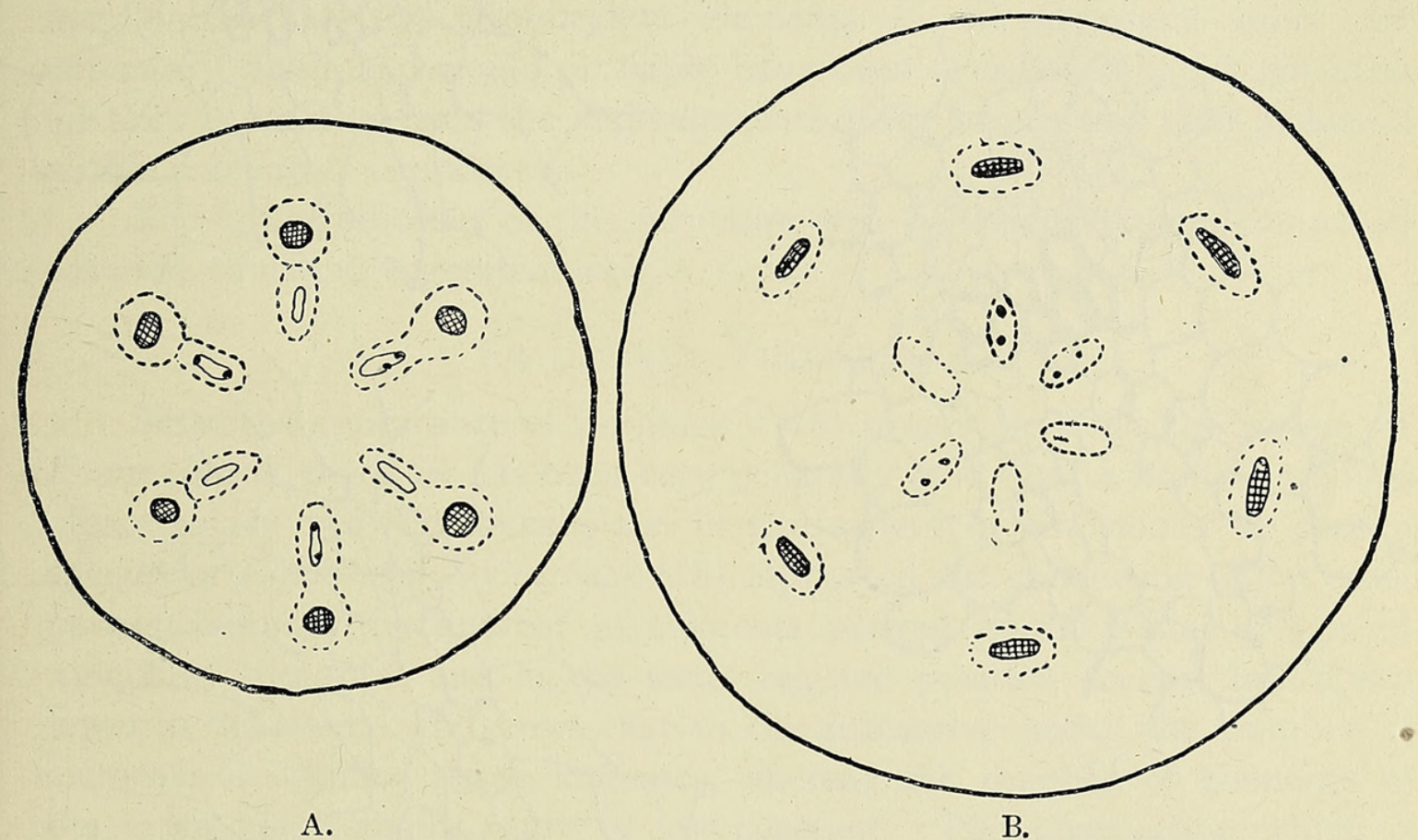

TeXT-FIG. Io. Diagram of transverse sections of abnormal tuber. A. Close below a node. B. Middle of the internode.

again before passing through the nodal region. The same author has pointed out that each vascular bundle is made up of mixed tracheides and parenchyma, and the xylem does not show a separation into three parallel strands.

Among the material examined during the present investigation one tuber of $E$. arvense was met with which exhibited a distinctly anomalous structure. It was noticed that in transverse section the bundles appeared to be much elongated in the radial direction, and on closer inspection it was found that the protoxylem, consisting of one or two extremely narrow elements, was separated from the remaining xylem by a group of parenchymatous cells, the endodermis encircling the whole bundle (Text-figs. IO (A, B), II, and I2). A series of sections was taken through the remainder of the internode, and from this it was seen that towards the widest region of the 
tuber these protoxylem elements remained relatively in their original place, while the remaining elements of the bundle occupied a more peripheral position. As the separation became more extreme, one endodermis no longer surrounded both parts, but separate ones encircled each portion of xylem (Text-figs. IO (B) and I 2).

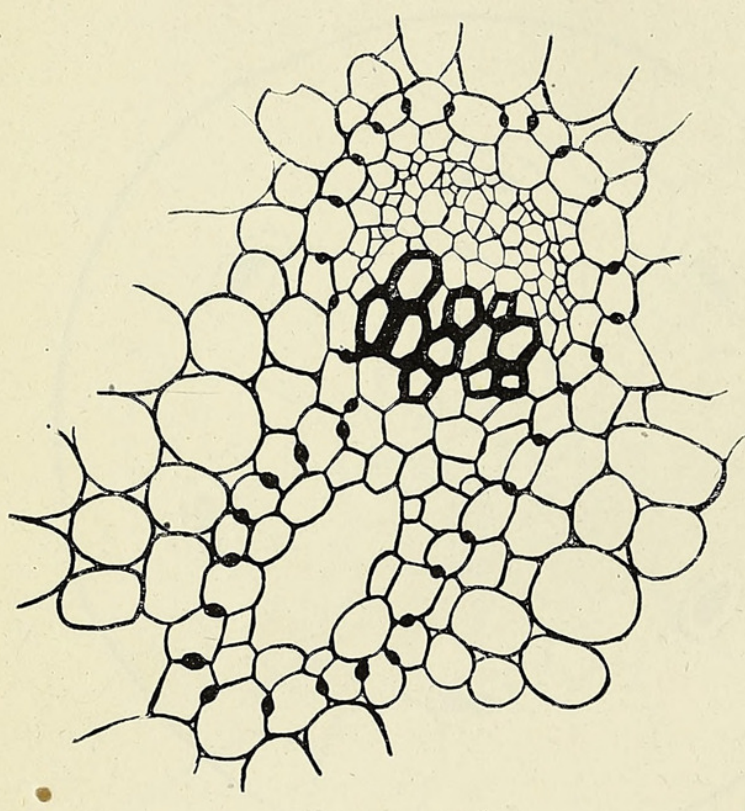

I I.
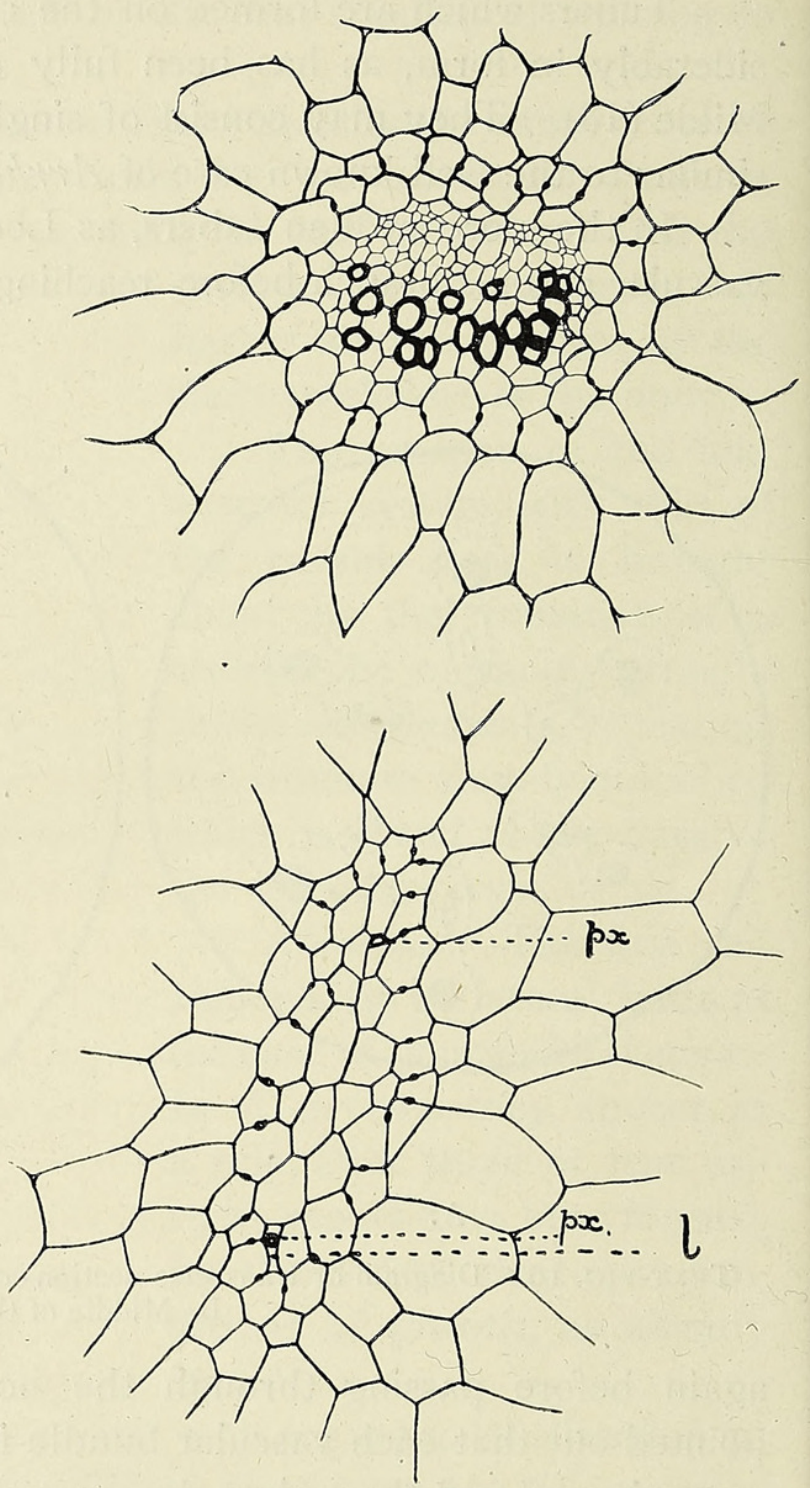

I 2 .

TEXT-FIG. II. Transverse section of a vascular bundle of an anomalous tuber of E. arvense close below a node. The carinal canal is clearly visible and is enclosed with the remainder of the bundle by a common endodermis.

TEXT-FIG. I2. Transverse section of a bundle from the middle of the same internode of anomalous tuber. The protoxylem is separated by a considerable radial distance from the metaxylem, and is enclosed in a separate endodermal sheath. Much of the parenchyma separating the two bundles in the radial direction has been omitted. $p x=$ protoxylem; $l=$ lacuna. $\times 180$.

The relatively small number and small size of the protoxylem elements and their separate position in this anomalous tuber thus suggest that the bulk of the tracheides present in the normal bundles represent the counterpart of the metaxylem of the aerial shoots and cone axis. 
A considerable amount of material was looked over in order to find other specimens with a similar structure, but without success. It seems clear, however, from this one case that the xylem in the bundle of the normal tuber consists of a relatively large mass of tracheides comparable to the lateral strands of metaxylem found in the typical vegetative internodes, while the protoxylem associated with the carinal canals of the latter is usually indistinguishable in the mature tubers. It is not suggested that this is not present at all, but if formed is there in very small amount, and owing to the tremendous development of parenchyma and consequent radial extension the small canal formed by its disruption becomes obliterated and the remains of the elements are no longer visible. It has already been mentioned that the protoxylem elements of the abnormal tuber are extremely small, and would probably have been overlooked had it not been for their separation from the main elements of the bundle and their inclusion within a separate endodermis.

The full significance of this structure will be evident when compared with the cone and vegetative axis.

\section{SECONDARY THICKENING.}

Since the appearance of Cormack's (15) observations on the xylem of E. maximum, the view has been very generally held that a limited amount of secondary growth takes place in the xylem of the nodes of certain species of Equisetum. Cormack (15) supported his conclusions by a comparison between the number of elements present in the nodal groups of xylem at the apex and in the same relative position several internodes lower in the stem. He shows that in the successive nodes the number of elements of lignified tissue increases, whereas the number of elements of the internodes remains more or less constant. This observation, which is readily confirmed, does not necessarily prove the point, for the increase in number of elements as seen in transverse section may be due to other causes than multiplication by cambial cell division. Longitudinal sections were examined in order to determine whether this 'increase' at any particular level had not been produced by the elongation of the elements in question accompanied by displacement due to sliding growth.

To determine whether this has actually happened, it is necessary to measure the lengths of the elements in the various regions and to examine critically the relation existing between the cells of the nodes and the internodes. In $E$. arvense, some dormant underground buds were fixed and sectioned in a longitudinal direction. These buds were particularly favourable for such an investigation because the numerous nodes in each bud showed every stage in the development of the xylem.

Similar buds of E. maximum were also examined and the same conditions were found. The drawings and measurements were, however, made 


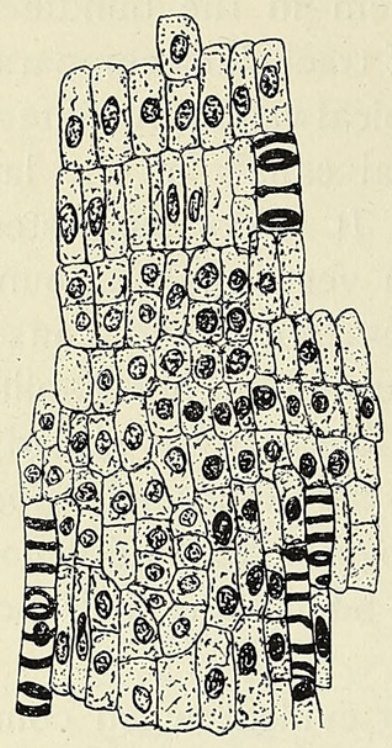

I3.

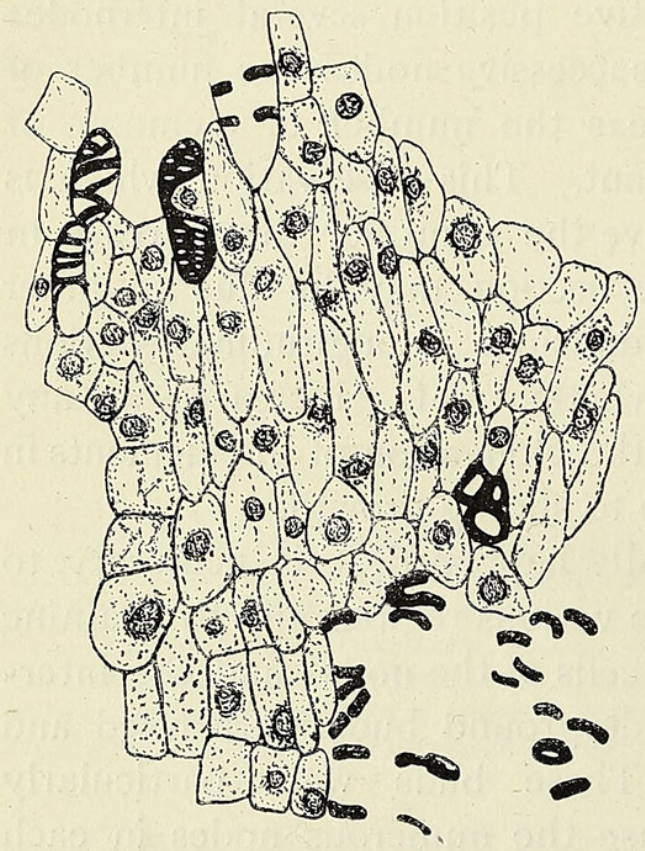

I 5 .

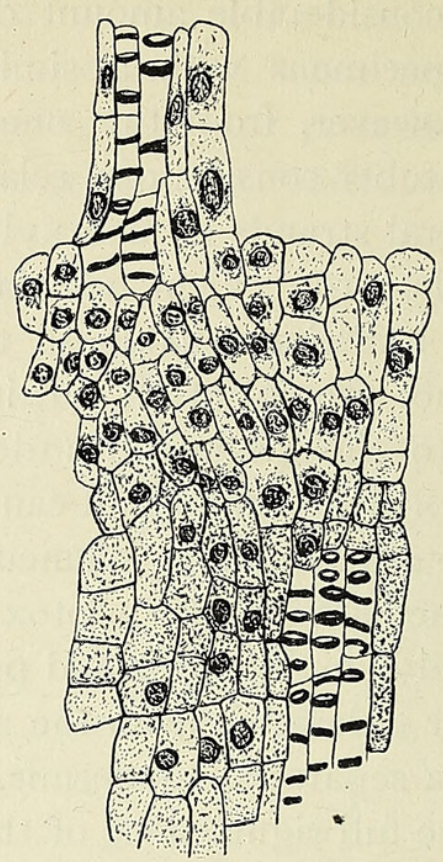

I4.

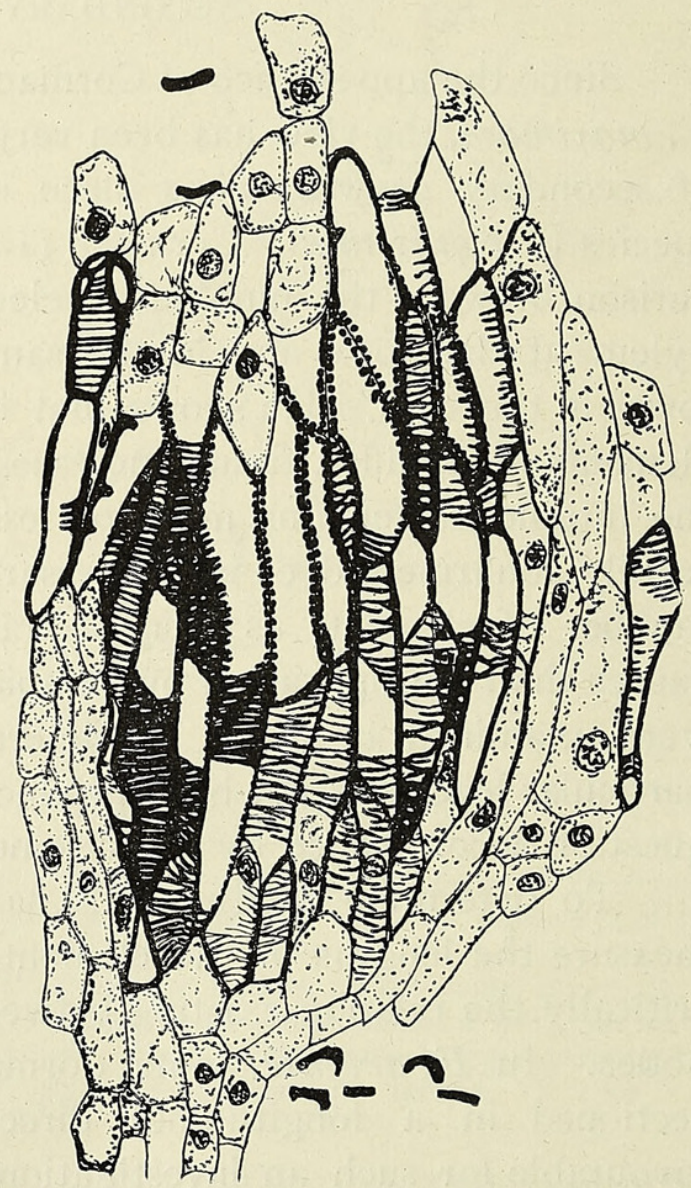

16.

TEXT-FIGS. I 3-I6. Cells of the node of a vegetative bud of $E$. arvense seen in longitudinal tangential view, showing four stages in the development of the nodal tracheides. $\times 275$. 
from specimens of $E$. arvense, owing to the more convenient size and shape of the buds.

Text-figs. I3-I6 show groups of nodal elements drawn from the nodes of an apical bud. From these it will be seen that the shape of the elements gradually changes from short cubical cells to slightly elongated elements tapering at both ends. The first change involves a slight lengthening of each element. Since little or no growth is taking place in the surrounding cells, the elongation of these xylem elements necessitates some special accommodation. This is brought about by an overlapping of the ends of the cells and an inclination of their long axes. All the elements of a group have the same inclination, though the direction is reversed in contiguous bundles, as seen in tangential sections. As the elongation of these elements proceeds, it is accompanied by an increase in diameter, and finally the walls are thickened in a reticulate pattern and lignification completes the development.

The cells which are destined to compose the nodal regions of the stem are sharply marked off from the internodal elements, which multiply rapidly later. The former are cubical parenchymatous cells arranged in very symmetrical rows, about four tiers of such cells being concerned in the formation of each node.

When the tracheides are fully grown, but before they lose their protoplasmic contents, the position of the nuclei still gives a rough indication of the original arrangement of the cells. If these groups of cells were sectioned in a transverse direction it would naturally appear as if the number of elements had increased as the node became older. This increase, however, is brought about by the overlapping of previously existing cells, and cannot in any way be referred to a process of secondary thickening. Each element in longitudinal view is seen to overlap one-two cells, which would result in an apparent multiplication by two or three, and on counting the number of elements present in a number of groups as seen in transverse section the average increase corresponded very closely, i.e. rather more than two.

The examination of preparations of E. maximum lead to the same conclusions, and it would seem, therefore, that in these two species the facts on which the existence of a process of secondary growth has been based are susceptible of a simpler explanation, although one which perhaps will not be so acceptable to palaeontologists.

\section{A Forked Vegetative Axis.}

Several authors have already described cases of branching in cones of Equisetum, and Stiles (16) has investigated the anatomy of a branched strobilus of $E$. maximum. He accepts the view put forward by Bower $(17$, p. 682) that the branching of the strobilus is fundamentally dichotomous. It is interesting, therefore, to be able to record an example of an apparent 
dichotomy of a vegetative axis. One of the sporelings of E. limosum, grown in culture, was found to have a forked primary axis. Only one such case was seen, the forking of the axis taking place at the level of the fifth node. The specimen was cleared and stained with ammoniacal fuchsin so that the vascular strands stood out clearly.

It may be seen by reference to Text-fig. $I 7$, that the vascular strands

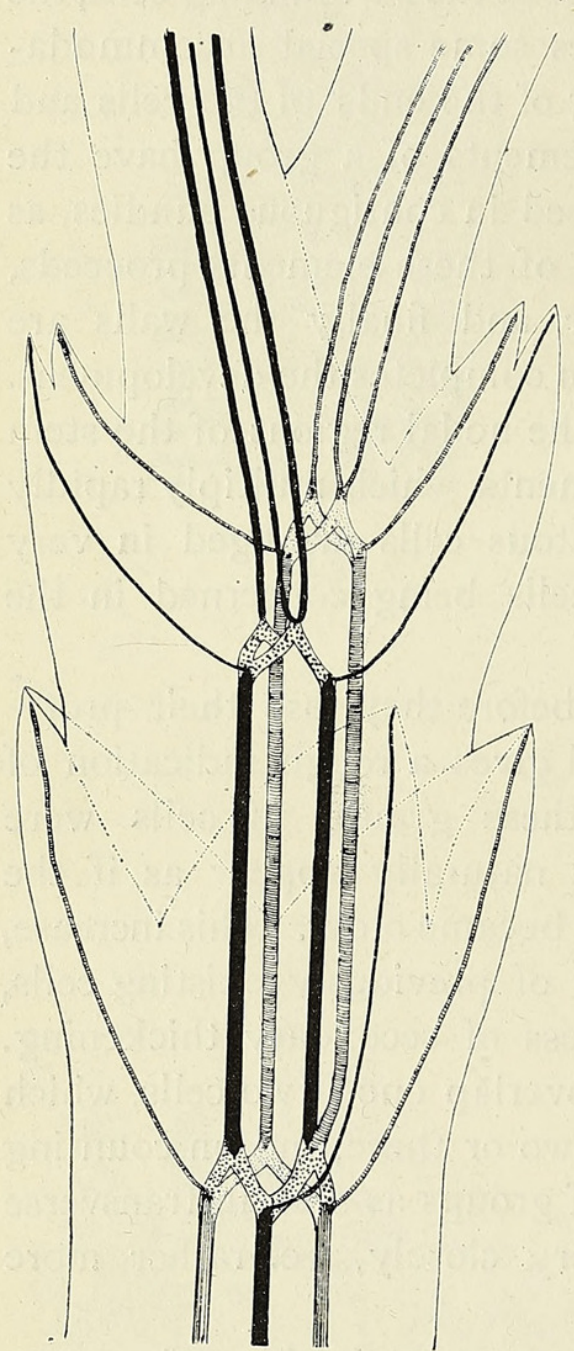

TeXt-Fig. I7. Diagram illustrating the vascular sysiem of the sporeling of $E$. limosum with the forked axis. The difference in level of the two nodes in the common axis is real and not due entirely to perspective. of the two branches run for a short distance as separate systems in the partially fused stem, and two nodes with the intervening internode are involved in the adjustments of the vascular system. The changes so necessitated include a reduction of six strands to three, and this takes place in two stages. The normal number of leaves for the sporeling is three, but at the node near the point of forking four appendages are present. The vascular system of the two branches shows greater independence at this region than do the external tissues; there are in fact two distinct vascular cylinders, and a separate nodal organization is present for each branch. Each of these supplies traces to a pair of leaves.

In each case the three bundles of the branch are continued by two in the internode below. The reduction is effected by two bundles approximating immediately above the node and linking up with the same group of nodal tracheides. At the node below the four strands, two from each branch are similarly replaced by three in the next internode. It may be pointed out that this simple method of varying the number of bundles in adjoining internodes is that normally followed in ordinary shoots.

It is evident from the facts described above that this is not a case of vigorous development of a lateral branch, but a true forking of the primary axis.

\section{The Structure of The Cone.}

A careful and detailed account of the structure of the cone of four species of Equisetum has been given by Lady Isabel Browne $(1,2)$. Cones of each of these species were cut into series of transverse and longitudinal 
sections, from which diagrams of the whole vascular system were constructed.

Browne concludes that the species examined can be arranged in a series which shows a progressive reduction in the amount of xylem tissue. This ranges from a regular arrangement in $E$. arvense, imperfectly siphonostelic at the nodes to dictyostelic in the internodes, through $E$. palustre, E. maximum, to E. limosum, where the xylem is reduced to an irregular network. This reduction in the xylem is accompanied by an increase in size of the parenchymatous meshes which separate the bundles, and in $E$. palustre these meshes often extend through the nodes, with the result that the vascular strands tend to run longitudinally with few anastomoses and are separated by relatively wide parenchymatous tracks.

Browne describes the detailed nature of the vascular bundles, and draws attention to the difference between those present in the strobilus and those occurring in the vegetative axes. She considers that the anatomy of the cone axis supports the view that the sporangiophores are whole appendages of a foliar nature, and interprets the structure of the cone in terms of nodes and internodes. Browne agrees with most authors in regarding the annulus as a modified leaf-whorl.

- In the present investigation cones have been prepared in the way already described for the vegetative organs : they were cut in half longitudinally, cleared, and stained in bulk. By this method a large number of specimens of different species could be prepared in a relatively short time and the individual variability appreciated. Both very young and mature cones were thus prepared in order to trace out the ontogeny of the vascular system.

The first impression gained from an examination of the cone is the marked differences in structure it presents as compared with the vegetative axis. Of these the most striking are the apparent absence of lacunae, both vallecular and carinal, and the structure of the vascular bundles.

Browne (1, p. 684) has pointed out that instead of the three groups of xylem, characteristic of the bundles of the vegetative internodes, the bundles of the cone show a narrow tangentially extended band of tracheides, and suggests that 'in the vegetative internodes the lateral groups of xylem represent the free ends of a more deeply curved band of xylem, and in that case the position of the tracheides of the lateral groups of metaxylem in a radial series is due to the more or less marked curvature of a band of which only the carinal tracheides and the free ends are lignified. The primitive form of the internodal bundle would then be that of the cone.'

She further states $(1$, p. 666) : ‘. In a good many places there are, internally to the bands or ring, isolated tracheides or little groups of tracheides, usually of smail size ; . . . Such tracheides or groups of tracheides do not as a rule persist for any considerable distance in a vertical direction; 


\section{2}

\section{Barratt. - A Contribution to our Knowledge of the}

in the internode they occur also internally to the separate strands of xylem.' It may be stated quite definitely that these elements belong to the protoxylem, although Browne does not apparently identify them as such, and, as will be shown below, they form a definite system of strands and constitute the scaffolding on which the whole vascular system of the cone is built up.

The species examined were $E$. maximum, E. arvense, E. limosum, E. palustre, E. sylvaticum.

In very young cones of $E$. palustre ${ }^{1}$ the development of the xylem could be readily made out (Text-fig. I8). It proceeds in a manner in no

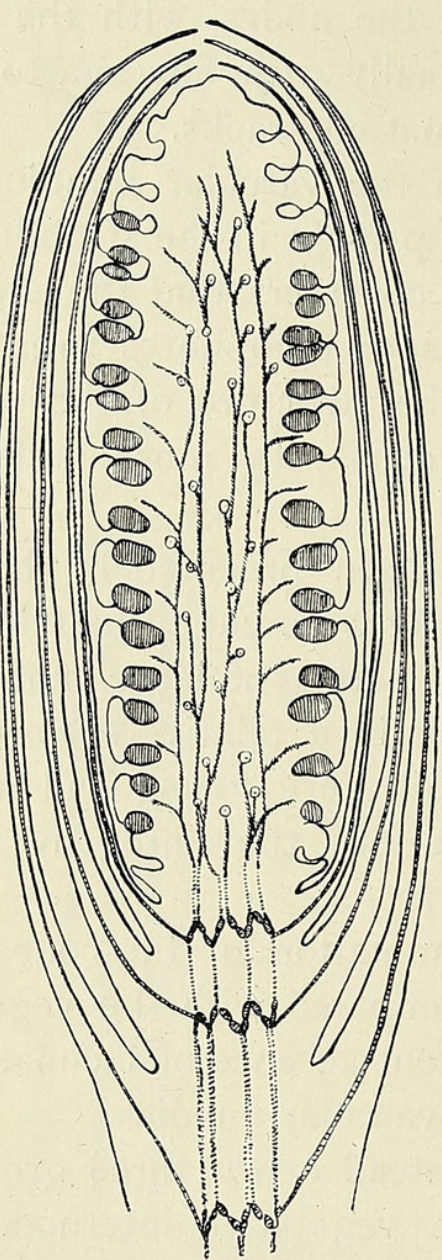

18.

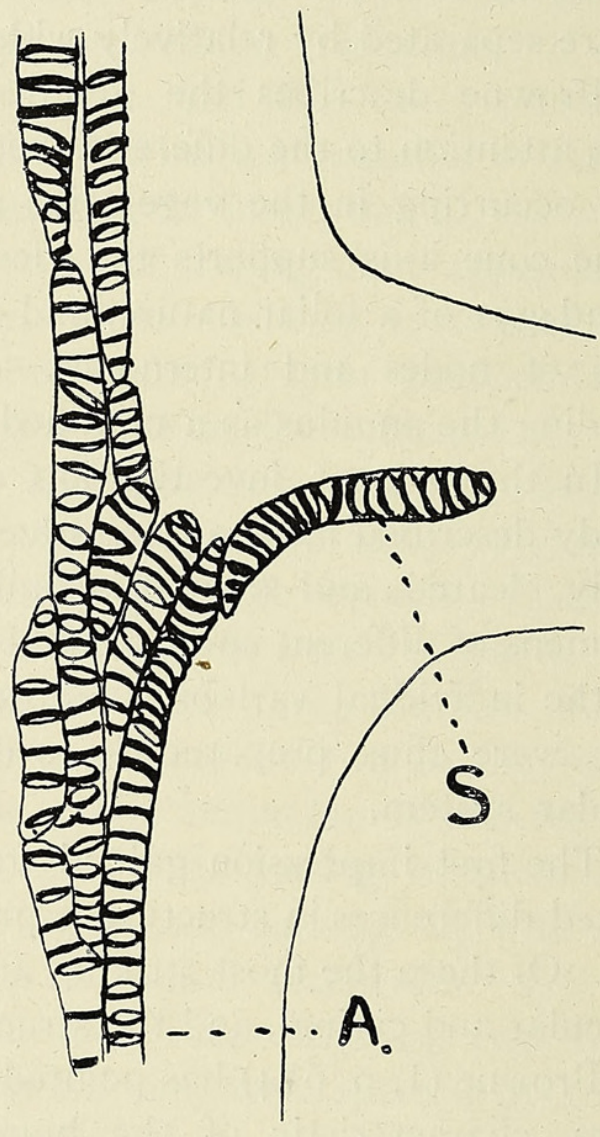

I 9.

TEXT-FIG. I8. Diagram representing half a young cone of $E$. palustre. The sporangiophores and leaves are somewhat diagrammatic, and the small circles surrounding dots in connexion with the vascular strands represent the points of connexion of the sporangiophore traces not otherwise shown. The protoxylem strands were traced with a camera lucida.

TEXT-FIG. I9. Xylem strand of cone and the first differentiated tracheide of the sporangiophoric trace from young cone of $E$. palustre. $\mathrm{A}=$ axial strand of cone ; $\mathrm{S}=$ sporangiophoric trace.

way comparable with that of the vegetative axis. In the latter, the several protoxylem strands of each internode develop simultaneously. Their

1 Cones of $E$. arvense and E. maximum were collected in the autumn and found to be fully formed. As Browne pointed out for $E$. arvense, the vascular system is at this time practically mature. E. palustre was therefore selected owing to the fact that the cones are formed at the apices of the vegetative axes, and can be very easily collected at an early stage. 
development is quite independent of those in the internodes above and below, with which they are subsequently connected by the nodal tracheides. In the cone, however, the protoxylem strands develop uninterruptedly from the base to the apex of the cone. There is no disjunction at the 'nodes', though some of the strands may terminate at or near the point of insertion of the sporangiophores. Moreover, the traces of the latter arise in a manner quite different from those of the leaves. The differentiation of the tracheides of the leaf-traces begins in the distal part of the leaf and proceeds inwards until they finally link up with the nodal tracheides. In the sporangiophore trace the order of development is reversed. The first tracheide differentiates next to an axial strand of protoxylem, to which it may be connected laterally or terminally, and the further differentiation of the strand proceeds outwards into the stalk of the sporangiophore (Textfig. 19).

In any comparison of the vascular structure of the cones and vegetative shoots, such marked difference in the arrangement and mode of development of the protoxylem strands must receive full consideration. They are features which would be least affected and longest retained in any process of reduction. In the vegetative shoots the leaf-sheaths, though now of comparatively small importance in the economy of the plant, have a dominating influence on the vascular structure of the stem. The sporangiophores, though provided with a vascular system of relatively better development than that of the leaf-teeth, have no similar effect on the anatomy of the cone.

The examination of mature cones of such species as $E$. arvense and E. maximum, with more or less regular whorls of sporangiophores and with well-developed metaxylem masking the protoxylem strands, may perhaps suggest an internal organization of node and internode. A study of the development of the vascular system, however, can only lead to the conclusion that the vascular structure so characteristic of all the mature vegetative axes, with its well-defined segmentation, is quite absent in the cone.

With the appearance of metaxylem tracheides in the axis-which takes place somewhat irregularly-additional elements are added to the sporangiophore traces, which when completed show a mesarch structure as described by Eames (19). The axial metaxylem consists of spirally thickened tracheides which vary considerably in length. The advantage of this type of tracheide is evident in view of the rapid elongation of the cone which takes place at the time of dehiscence of the sporangia.

As seen in transverse sections (Text-figs. 20 and $2 \mathrm{I}$ ), the metaxylem is separated from the protoxylem by parenchymatous cells, and as the cone matures it forms a continuous band, 2 to 4 cells wide, external to the protoxylem in each bundle. The greater development of the metaxylem tends to mask the presence of the protoxylem. The latter, however, is 
always present and is most conspicuously seen in transverse section in cones of the shape found in E. palustre. There the growth in length is relatively

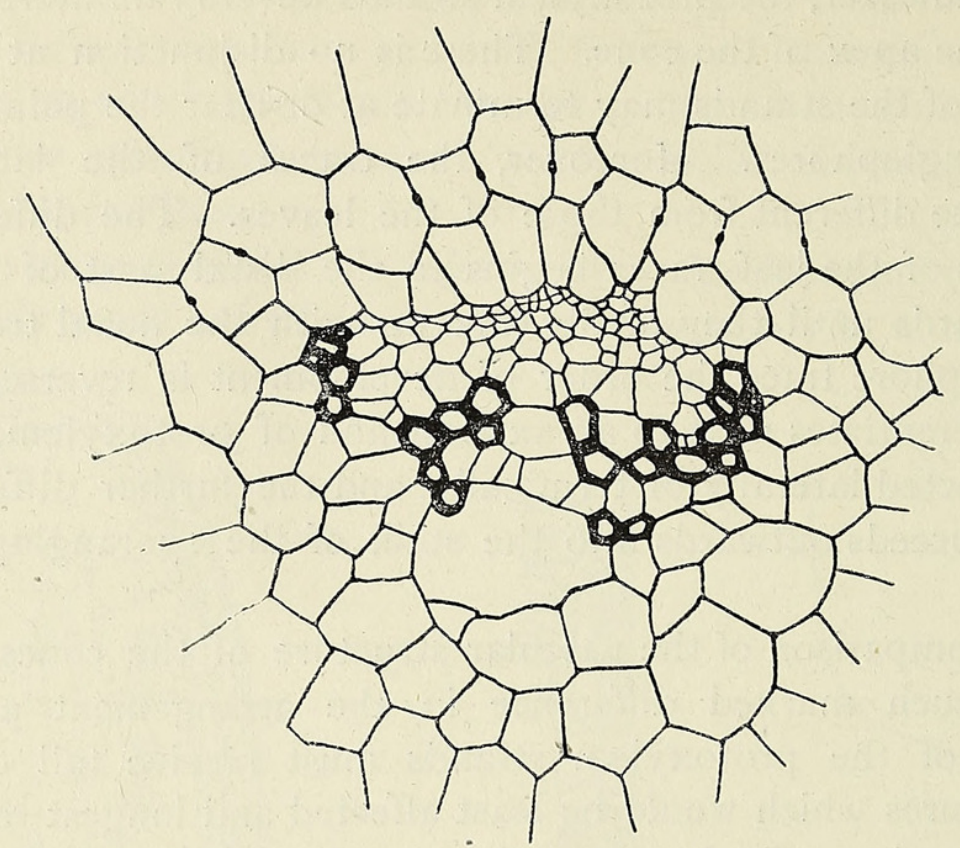

Text-Fig, 20. Transverse section of bundle from cone of $E$. palustre. Note the carinal canal. $\times 275$.

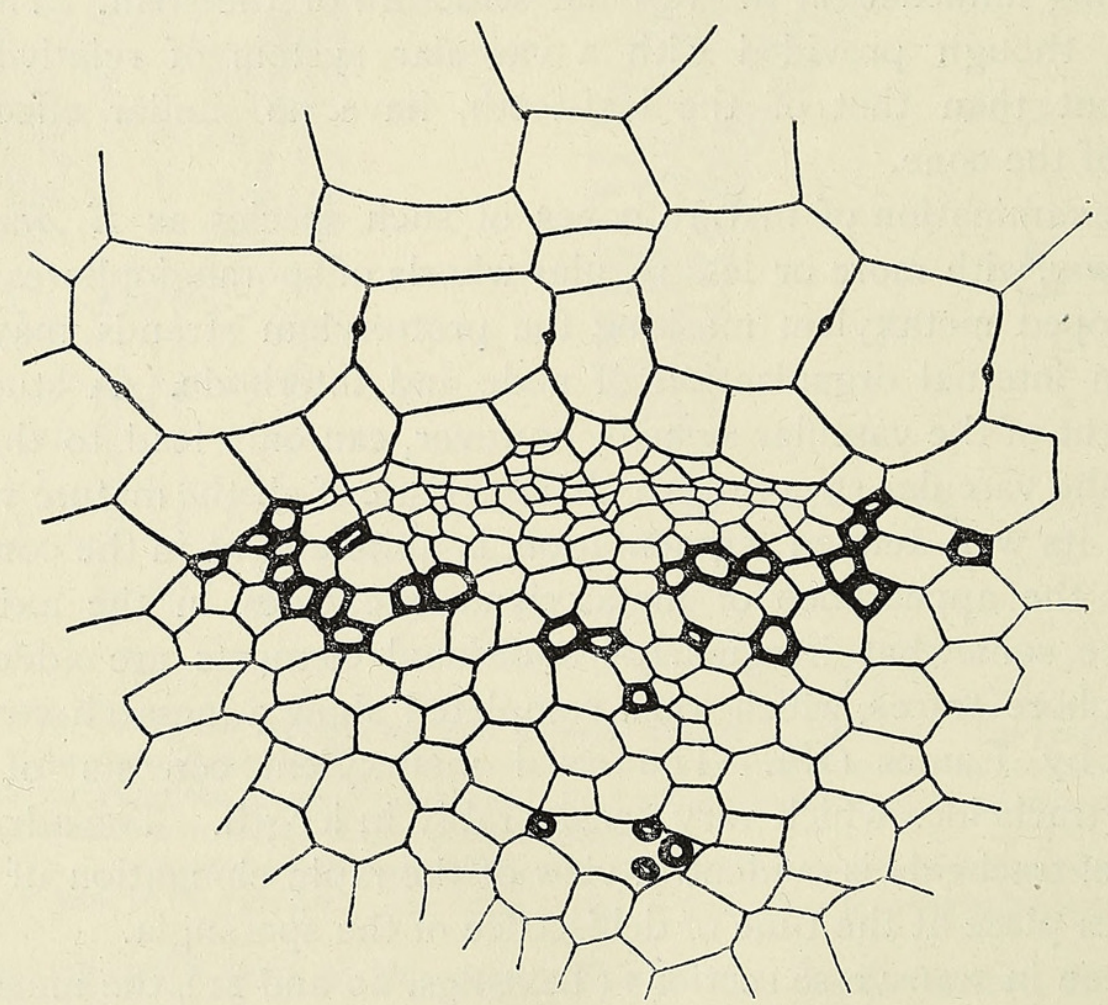

TEXT-FIG. 2I. Transverse section of bundle from cone of E. maximum. Note the scattered arrangement of the metaxylem and the position of the protoxylem. $\times 275$.

great, bringing about a more complete rupture of the protoxylem and consequently the formation of small lacunae (Fig. 20). The relation between 
the structure of these bundles and that of the bundles of the vegetative stems will be discussed below.

Although, as already stated, the protoxylem strands determine the main features of the vascular system, yet the very considerable development

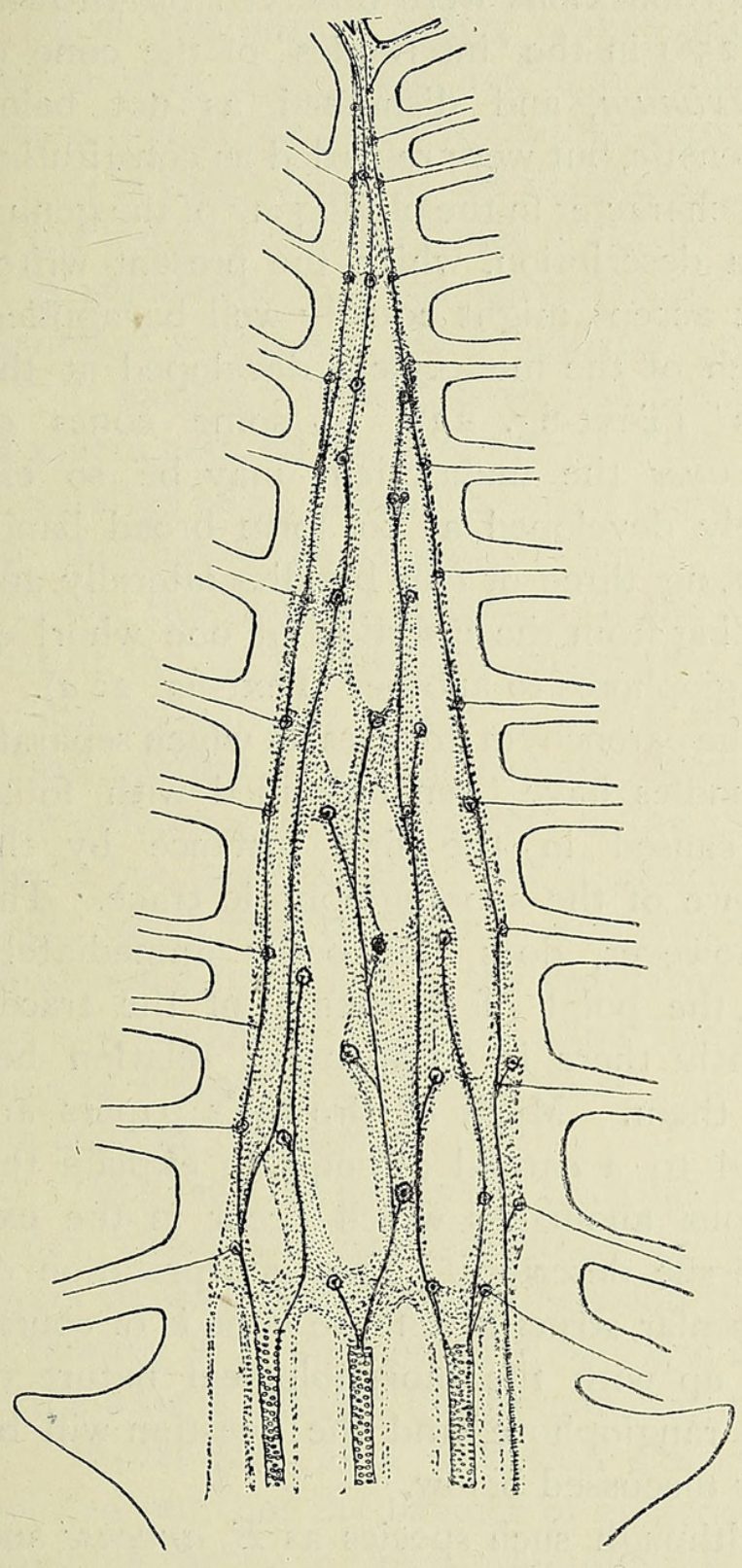

22.

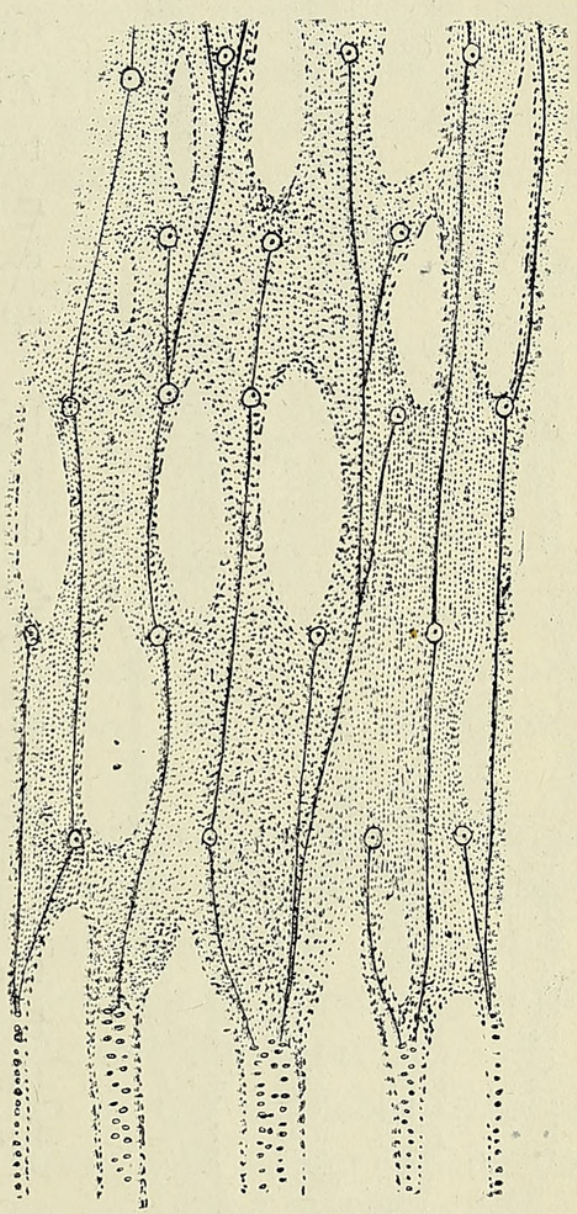

$22 \pi$.

TEXT-FIG. 22. Diagram illustrating the vascular system of the cone of $E$. arvense. The metaxylem is represented by shaded area and the protoxylem by continuous lines. The black circles enclosing central dots represent the point of attachment of the sporangiophore traces.

TEXT-FIG. $22 a$. Part of the vascular system of a cone of $E$. arvense, showing more extensive tracts of metaxylem.

of metaxylem in the bundles may tend to obscure the course of the primary strands (Text-figs. 22 and $22 \alpha$ ). Moreover, the metaxylem may be unequally developed on either side of a protoxylem strand, and may in certain regions be so well developed as to form lateral connexions with 
neighbouring strands. This is, in fact, what frequently happens at the 'nodes', the anastomosing and forking of the bundles having in many cases no relation to the behaviour of the primary strands, although of course forking

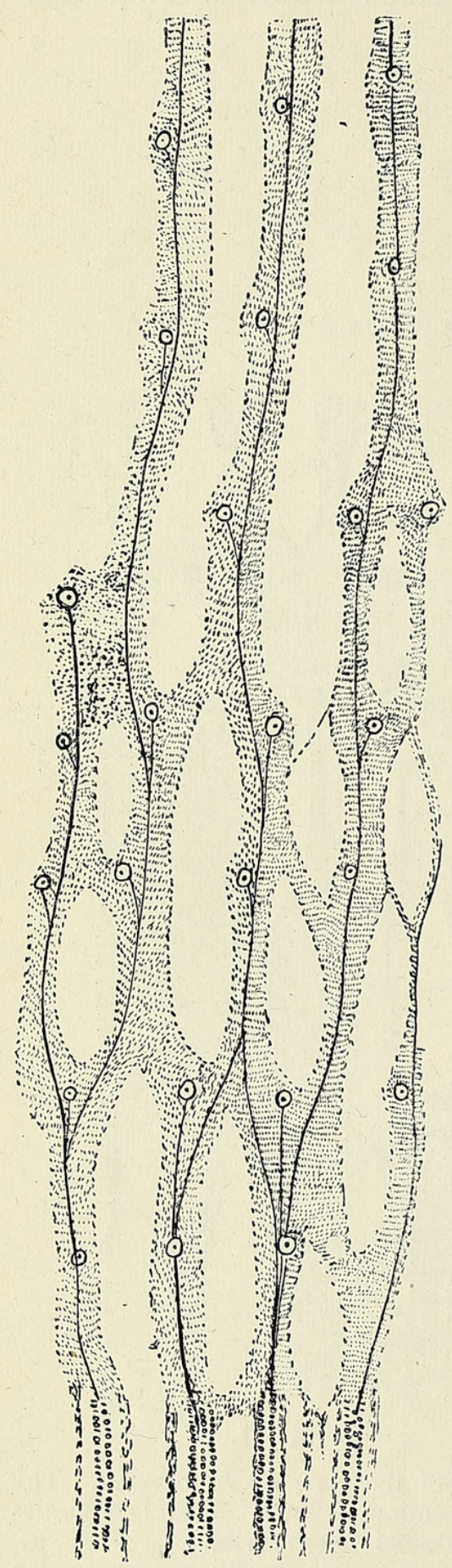

TeXT-FIG. 23. Diagram illustrating the arrangement of the xylem strands of a cone of E. maximum.

of the primary strands does occur. Such lateral connexions were observed by Browne $\left(2\right.$, p. $\left.25^{8}\right)$ in the 'internodes' of the cone of $E$. maximum, and dismissed as not being palingenetic, but were regarded as constituting a fresh character in the phylogeny of the genus. Such a description, which the present writer cannot accept, might equally well be applied to much of the metaxylem developed at the 'nodes' (Text-fig. 23). In some cones of $E$. arvense the metaxylem may be so extensively developed as to form broad bands connecting three or four bundles laterally and extending from the insertion of one whorl of sporangiophores to another (Text-fig. $22 a$ ).

The parenchymatous tracts which separate the bundles have been identified with foliar gaps, caused in the first instance by the departure of the sporangiophoric trace. The gap, however, does not occur immediately above the point of departure of the trace; frequently there is no apparent relation between them. Much of Browne's papers are devoted to a careful attempt to explain the numerous anomalies which occur in the examples she describes. This interpretation of the vascular structure of the cone is of course bound up with the morphological nature of the sporangiophore, and the question will be further discussed below.

Although such species as $E$. arvense and $E$. maximum show a definite network of strands with short meshes, in E. palustre, E. limosum, E. sylvaticum, the meshes are more irregularfrequently much elongated-stretching through two or more 'nodes', and in E. palustre even extending nearly the whole length of the cone. Browne (1, p. 699) ascribes these differences to a reduction of the xylem which, operating at the nodes, has produced an 'extension of the parenchymatous meshes upwards, downwards, and laterally,' 
There is no question that in certain species the xylem is less well developed than in others, and it is possible to arrange the species as Browne has done in a reduction series. Whatever factor may have been operative in bringing about this reduction of the xylem considered as a whorl, the present writer cannot admit that it has been influential in determining the course and distribution of the xylem strands and the disposition of the parenchymatous gaps.

It is suggested that the determining factor in the relative development of the metaxylem, and hence of the meshes, is primarily a mechanical one. It is significant that the species with large and heavy cones have more abundant xylem and more regularly developed network.

It has been shown above that the arrangement of the primary strands of xylem and the mode of origin of the sporangiophore traces do not lend themselves to an interpretation of the vascular system of the cone as built up, like that of the vegetative stem, of an alternation of node and internode. If, then, the vascular structure of the cone is so strikingly different from that of the leafy shoot, the contention that the sporangiophore is a foliar structure-whether whole or part of a leaf-loses much support. In Calamostachys, as Williamson and Scott (18) have shown, there is a remarkable difference in the structure of the axis at the region of insertion of the sterile bracts and at the level of attachment of the sporangiophores. The nodes which bear the bracts show essentially the same character (e.g. the short nodal tracheide) as the vegetative nodes of Equisetum; the traces of the sporangiophores, on the other hand, are inserted directly on the axial strands without interrupting them. In this respect they resemble those of the cone of Equisetum.

Hickling (19) points out that the so-called 'sporangiophore' or 'fertile nodes' should not be regarded as nodes in the same sense as the true or ' tract nodes'. With that conclusion the present writer must agree, and in extending it to the cone of Equisetum concludes that in the latter genus the fertile axis is entirely undifferentiated into node and internode.

Bower (17), after a careful consideration of the available data, has pointed out that the balance of evidence is strongly in favour of the nonphylome theory of the sporangiophore in Equisetum, and the facts brought out in the present investigation lend it still further support.

The annulus has generally been considered to be a foliar structure. Its morphology has been fully discussed by Goebel (20), and abnormal forms approaching foliage leaves on the one hand and sporangiophores on the other have been described by Milde (13), Glück (21), and others.

It is of some interest to consider to what extent this view is supported by the vascular anatomy of the cone.

Just above the level of the insertion of the annulus the characteristic vascular structure of the cone begins and the transition from the typical 


\section{8 Barratt.-A Contribution to our Knowledge of the}

internode below is marked by a considerable development of metaxylem at this point. This has been interpreted by Browne as affording indications of the presence of a node. According to Vidal's (6) conception of the vegetative axis of Equisetum as being made up of a series of segments each composed of a node with an inferior internode, the fact that there is an undoubted internode immediately below the insertion of the annulus would presuppose the existence of a node above. On the other hand, there are certain facts which negative such a view; these are (I) the course of the protoxylem strands, (2) the total absence of vascular supply to the annulus. The protoxylem strands from the internode pass without any disjunction to the level at which the first sporangiophore traces arise, and hence there is no alternation at the so-called 'node'. There may be apparent forking of the strands, but this is due to the fact that the protoxylem strands in the bundles of the internode below are often double, which, separating as they enter the cone, produce this appearance of forking. This appearance is emphasized by the disposition of the metaxylem at this region, which is similar to that at the so-called nodes from which the sporangiophore traces arise.

The absence of vascular tissue in the annulus has been frequently noted. In itself this is not an insuperable objection to the foliar theory because the ochreola which occurs at the base of all branches always lacks traces.

In this connexion it is interesting to consider certain abnormal annuli found among the material used in this investigation. Fertile annuli with well-developed sporangia were found in both E.palustre and E.sylvaticum. They varied in form; some were fully peltate (Pl. VI, Fig. 3), others bore sporangia only on the upper surface. Not one of the structures, however, possessed any trace of a vascular system.

On the whole, therefore, though the vascular structure does not support the view of the foliar nature of the annulus, it cannot be said to throw much light on the morphology of this organ.

\section{Discussion and Summary.}

In order to arrive at a true conception of the vascular structure of Equisetum it is necessary to look at the plant as a whole. Any general explanation or theory put forward must be capable of embracing characters found in all the organs of all the species.

It very often happens that a study of the structure of the early stages of the individual throws light on the phylogenetic history of the genus. Jeffrey (4), in his account of the sporeling of E. hiemale, describes the vascular system at the base of the first shoot as siphonostelic, but it is clear from a study of sporelings of E. arvense and E. maximum, that the vascular cylinder at the base of the first shoot in these species is protostelic. This 
condition does not persist for long; it is temporarily disturbed by the attachment of the first lateral branch, and above the first node the solid cylinder opens out at once into the much-reduced structure of the internode. Such a protostelic condition is not met with in the succeeding shoots. A very characteristic and significant vascular formation is found in the compound structure formed from the bases of the first few aerial shoots. This is a continuous sympodial siphonostele uninterrupted by leaf-traces or parenchymatous gaps of any kind. It is also significant that a siphonostele is to be found at the base of every branch, whether borne above or below. ground, and that it is repeated at every node of the vegetative shoots.

The internode undoubtedly shows a much reduced vascular development, and we must look for an explanation of its characteristic structure in the plant organs which have suffered less reduction. The structure of the basal regions already referred to above provides a very strong argument for a siphonostelic origin, and there seems to be small reason to doubt that the bundle arrangement now present in the internodes is the final stage in reduction from such a condition.

Gwynne-Vaughan (9) first raised the question as to the true nature of the lateral strands of internodal xylem, and Poirault (22) agreed with him in his conclusion that they had no connexion with the leaf-trace system, but were continuous over the nodes, and that their development was in a centripetal direction.

Gwynne-Vaughan suggested that these strands may represent the last remnants of a central mass of centripetal xylem. This view was seriously attacked by Eames (10), who not only thought that the whole xylem of each bundle made up a unit, but that all parts were involved in the formation of the leaf-traces.

From the present investigation it seems certain that the order of differentiation of the elements of the lateral strands is in general centrifugal, as the majority of the later investigators (Quéva (7), Browne (1)) have agreed. Eames (10), however, seems to have overlooked the fact which Janczewski (8) and Quéva (7) had previously noted, that the xylem of each internode develops quite independently, only linking up subsequently by the development of the nodal tracheides. He, in fact, speaks of the carinal canals as disappearing at the nodes and their place being occupied by largecelled protoxylem. The protoxylem certainly does not traverse the node, and no elements of that region can be described in such terms, since they are all alike in character, agreeing in their short length and in bearing reticulate thickenings.

The true nature and relations of these various strands of xylem can be seen by reference to other organs. In the first place the bundles of the tubers give us a clue. There the xylem is not separated into three strands; but forms a continuous group of tracheides, though often interspersed with 
parenchymatous cells. The protoxylem is poorly developed and the elements not ruptured, hence a carinal canal is absent. Quéva's figure (7, p. I35) of a bundle from E. litorale may be compared with Text-fig. 9.

We obtain, however, still further enlightenment from an examination of the cone.

In the latter organ the predominance of metaxylem is very striking, the protoxylem being represented by relatively few and small elements well to the interior of the irregular bundles. The order of differentiation in the following species, E. arvense, E. maximum, E. palustre, E. limosum, E. sylvaticum, was undoubtedly centrifugal, but the existence of mesarch traces in the sporangiophores gives credence to Eames's (10) view that the cones of E. hiemale and E. fluviatile exhibit mesarch axial strands.

Thus the internodal bundles of the aerial vegetative axis are seen to conform in structure with those of the tuber and cone. The lateral strands

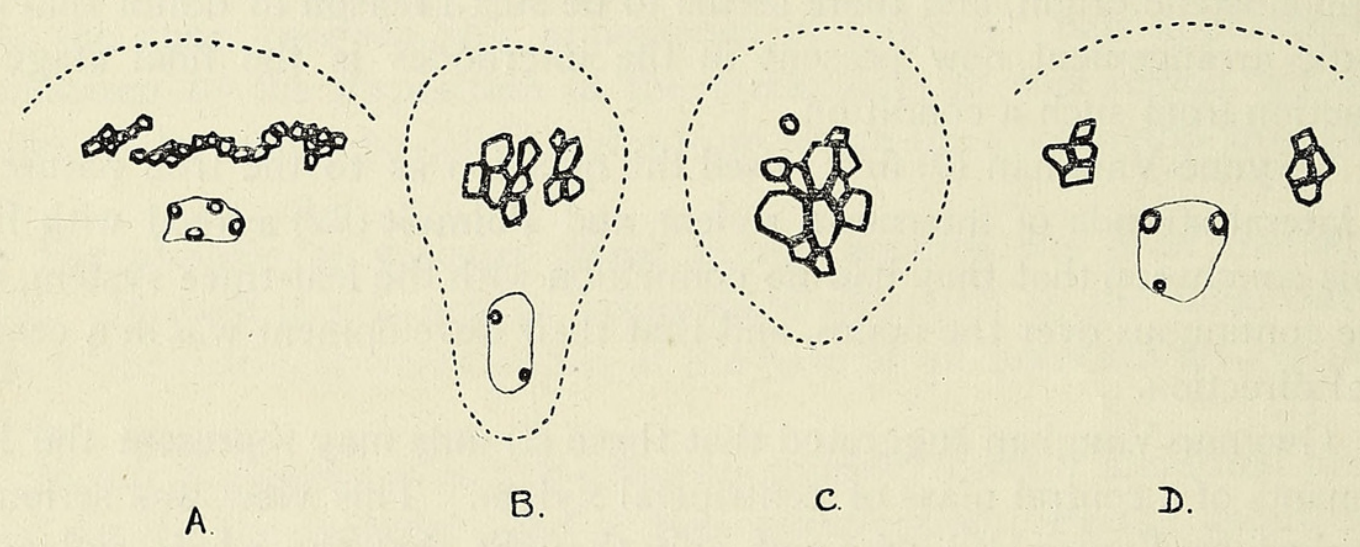

TEXT-FIG. 24. Diagram showing bundles from: A, cone; B, abnormal tuber; C, normal tuber; D, internode of stem.

are the relics of a continuous band of metaxylem such as now exists in the bundles of the cone and less perfectly in those of the tuber (Text-fig. 24).

A somewhat similar suggestion was put forward by Browne (1), who, however, regarded the carinal tracheides as representing the middle portion of the once continuous xylem. It has been shown above that in all cases the protoxylem forms an independent strand always internal to the metaxylem.

As Browne suggests, the vascular structure of the cones of some species shows a reduction series, much more xylem being present in the cones of $E$. arvense, for example, than in those of E. limosum. It is quite clear from an examination of the former of these species that the basal plan was a siphonostele in which gaps have arisen owing to the failure of the cells to differentiate as tracheides. On this conception the structure met with in the cone links together the unbroken siphonostele of the basal region of the young plant and the vascular structures of the node and internode of the vegetative axis. 
The reason for the extraordinary difference in character between the elements of the node and internode of the latter appears to be due to the difference in amount and rate of growth of those two regions. The internodal condition represents the last stage in a reduction of xylem consistent with a continuous and effective supply of water to the leaves and branches.

In the light of these facts it seems clear that the metaxylem found in the underground basal region of the sporeling, in the cone, the nodes and internodes of the vegetative branches, is all phylogenetically the same, i. e. it is the centrifugally developed wood of a monostelic system, differing only in the degree of reduction and the character of the elements.

With regard to the question of the addition of secondary elements to the centrifugal wood of the node of certain species, the results of the present investigation negative the presence of any process of secondary thickening. The facts on which this idea was based allow of a simpler explanation, viz. that the increase in length of the nodal elements, accompanied by sliding growth, gives an appearance in transverse section of an apparent increase in the number of tracheides of the xylem.

Having concluded that the existing structure in both vegetative and reproductive axes has been derived from a continuous siphonostele only interrupted by the insertion of the branches, we are faced with the problem of the determining factor associated with the distribution of the parenchymatous tracts. Can it be met by an application of the conception of foliar gaps which is associated with the study of filicinean anatomy? Browne has attempted such an explanation in her papers dealing with the cones of several species of Equisetum. She homologizes the parenchymatous meshes with foliar gaps, associating them with sporangiophores, and considers that these organs are modified whole foliar structures.

As stated more fully above, the detailed anatomy of the cone does not support the view that the sporangiophores are really of this nature, and, judged in the light of the anatony of a mixed strobilus such as that of Calamostachys, it cannot be doubted that nodes are completely absent in the cones of present-day Equiseta.

Even if the sporangiophores were foliar structures, the anatomy does not favour the view that the meshes are foliar gaps. Jeffrey has pointed out, and it is abundantly confirmed in this investigation, that the gap does not, except in a few cases, occur immediately above the point of departure of the trace; and most frequently shows no relation to it.

The theory put forward by Jeffrey (5), that the gaps in the vegetative axis can be described as ramular gaps, is certainly not supported by the anatomical facts described in this paper. The gaps are not situated immediately above the point of insertion of the vascular supply of the branch ; they fail, in fact, to satisfy the criterion on which Jeffrey himself insists in the case of foliar gaps. 
Whatever factors have been concerned in effecting the gradual lack of differentiation of wood recognizable as such, the actual areas of the xylem in which the replacement of tracheides by parenchyma has taken place have had no necessary relation to the insertion of leaves and branches. The present distribution of the xylem, and hence of the parenchymatous tracts, is such as to best preserve the efficiency of the wood in its double function of water-conduction and mechanical support. In the internodes of the vegetative axis, where the reduction of xylem has been carried very far, it has no doubt made possible the great elongation which is such a marked characteristic of the genus. The rigid tube of short tracheides at the nodes is an important factor in maintaining the mechanical efficiency of the stem. In the cones where the nodes are absent the greater development of metaxylem and its more equal distribution is adapted to provide for the support of the numerous sporangiophores.

In conclusion, it may be stated that in the writer's opinion the size and distribution of the tracts of parenchyma have no morphological value in the discussion of questions of phylogeny. The same may be said of that muchdebated tissue the endodermis. In Equisetum not only does it appear in various relations to the vascular tissues in different parts of the same plant, but its arrangement also varies in the corresponding organs of different species. Kashyap (23) has shown in E. debile that small groups of parenchymatous cells without any vascular elements may be surrounded by separate endodermes. The anomalous tuber described in the present paper may also be instanced.

It may be recalled in this connexion that similar cases of unusual and independent occurrence of an endodermal layer have been recorded in other plants, e. g. in the roots of Ruscus (Lewis, 24).

Whatever factors may have determined its distribution, they are probably physiological ones, which, however, can scarcely be satisfactorily elucidated in the present state of our knowledge.

\section{SUMMARY OF RESUlts.}

I. The sporeling of Equisetum arvense shows a protostelic condition at its base which opens to a siphonostele at the level of attachment of the vascular supply of the secondary axis. The protostelic condition is again resumed for a short distance below the level of the attachment of the first whorl of leaves.

2. The basal regions of the succeeding axes of the young plant possess a compact closed siphonostele composed of short reticulate tracheides. There is thus formed a sympodial vascular tube in which five or more axes may be concerned.

3. The secondary axis arises endogenously from the primary axis below the level of the first leaf-whorl. 
4. The vascular structure of an anomalous tuber is described, in which carinal canals are formed in connexion with the protoxylem, and these in the middle region of the tuber are enveloped by separate endodermes.

5. A young sporeling of E. limosum is described showing a forked. primary axis. The arrangement of the vascular system indicates that it has almost certainly arisen by a dichotomy.

6. The question of the existence of secondary thickening at the nodes of $E$. arvense and $E$. maximum has been investigated by a study of the development of the nodal tracheides. The conclusion is formed that the apparent increase in elements which has been attributed to secondary thickening is due to the enlargement and displacement of developing tracheides.

7. The vascular structure of the cones of E. arvense, E. maximum, E. palustre, E. limosum, and E. sylvaticum is described.

The endogenous protoxylem strands are shown to form complete and continuous systems, uninterrupted by nodal tracheides, as is invariably the case in vegetative shoots. The metaxylem develops later and varies in amount and distribution in the different species.

$E$. arvense shows the greatest amount and E. limosum and E. sylvaticum the least.

It is concluded that the gaps in the metaxylem siphonostele cannot be described as leaf-gaps, bearing no relation to the sporangiophore traces, but may be related to the mechanical efficiency of the cone.

It is also concluded that the vascular structure of the cone indicates that the sporangiophores are not the morphological equivalent of leaves, but are organs sui generis, and the axis of the cone is undifferentiated into nodes and internodes.

8. The general vascular system of the plant is discussed, and it is concluded that the general plan of development proceeds from a simple protostele which opens out into a siphonostele. This shows a considerable reduction in the cone by the development of large parenchymatous meshes or longitudinal tracks and still further reduction in the internodes of the vegetative shoots.

In conclusion, the author's grateful thanks are due to Dr. S. Chandler, who very generously handed over some sporeling material and microtome sections of Equisetum sp., which he had already prepared.

Department of Botany, Imperial College of Science AND TECHNOLOGY. 


\section{BIBLIOGRAPHY.}

1. Browne, I. : A Contribution to our Knowledge of the Anatomy and Cone of the Fertile Stem of Equisetum. Annals of Botany, 19I2.

2. - A Second Contribution to our Knowledge of the Anatomy and Cone of the Fertile Stem of Equisetum. Annals of Botany, 19I5.

3. Hofmeister, W. : Germination, Development, and Fructification of the Higher Cryptogamia. Ray Society, 1862 .

4. JefFrey, E. C.: The Development, Structure, and Affinities of the Genus Equisetum. Memoirs of the Boston Society of Natural History, vol. v, No. 5, 1899.

5. - Are there Foliar Gaps in the Lycopsida? Botanical Gazette, I908.

6. Vidal, L. : La croissance terminale de la tige et la formation des bourgeons chez l'Equisetum palustre. Annales des Sciences naturelles, $9^{\circ}$ série, Botanique, vol. xv, I9I 2.

7. Quéva, C.: Histogenèse et structure du stipe et de la fronde des Equisetım. Mémoires de la Société d'histoire naturelle d'Autun, vol. xx, 1907.

8. Janczewski, E. DE : Recherches sur le développement des bourgeons dans les Prêles. Mémoires de la Société des Siences naturelles de Cherbourg, vol. xx, 1876 .

9. Gwynne-Vaughan, D. T.; Remarks upon the Stele of Equisetum. Annals of Botany, Igor.

10 Eames, A. J.; On the Occurrence of Centripetal Xylem in Equisetum. Annals of Botany, 1909.

11. Sykes, M. G.: Tracheides in the Nodal Region of Equisetum maximum. New Phytologist, 1906. Vol. v.

12. Duval-Jouve : Histoire naturelle des Equisetum de France. Paris, 1864.

13. Milde, J. : Monographia Equisetorum. Nova Acta Academiae Leopold: Carol, vol. xxxv, 1865.

14. Leclerc du Sablon: Sur les tubercules des Equisétacées. Revue générale de Botanique, vol. iv, 1892 .

15. Cormack, B. J. : On a Cambial Development in Equisetum. Annals of Botany, I893.

16. Stiles, W. : On a Branched Cone of Equisetum maximum. New Phytologist, 1906.

17. BOWER, F. O.: The Origin of a Land Flora. 1908.

18. Williamson, W. C., and ScotT, D. H.: Organization of the Fossil Plants of the CoalMeasures. Part I. Philosophical Transactions of the Royal Society of London, B., vol. clexxv, 1894 .

19. Hickling, T. G.: The Anatomy of Calamostachys Binneyana, Schimper. Memoirs and Proceedings of the Manchester Literary and Philosophical Society, vol. liv, Part III, Session $5909-10$.

20. Gozbel, K.: Über die Frnchtsprosse der Equiseten. Berichte der Deutschen Botanischen Gesellschaft, Bd. iv, i 886.

21. Glǘck, H. : Die Sporophyllmetamorphose. Flora, lxxx, I895.

22. Poirault, G.: Recherches d'histogénie végétale. Développement des tissus dans les organes végétatifs des Cryptogames vasculaires. Mémoires de l'Acad. imp. des Sciences de St.-

- Yétersbourg, $7^{\mathrm{e}}$ série, t. xxxvii, 1890.

23. Kashyap, S. R.: Notes on Equisetum debile, Roxb. Annals of Botany, 191 7 .

24. LEwIs, F. J.: Formation of an Irregular Endodermis in the Roots of Ruscus sp. Annals of Botany, I 900.

\section{DESCRIPTION OF PLATES VI AND VII.}

Ill ustrating Miss Barratt's paper on the Vascular System of the Genus Equisetum.

\section{PLATE VI.}

Fig. I. $a-g$. Drawings of sporelings taken from the same culture towards the end of the first season's growth. Note the great variation in size and development of the different plants grown on prothallia from spores sown at the same time. The prothallial lobes have been removed. Natural size. 
Fig. 2. $a$ and $b$. External view of lower parts of two sporelings, showing the position of the secondary axis. In $b$ it appears much nearer to the root than in $a$. The prothallus has been removed. $\times 68$. From drawings by Dr. S. Chandler. above.

Fig. 3. An abnormal annulus of $E$. palustre showing the development of sporangia. Seen from

Fig. 4. Longitudinal view of basal region of very young sporeling from a cleared preparation. The cortical tissues have been omitted. The endodermis is conspicuous owing to the cuticularized band staining deeply with ammoniacal fuchsin. Note the difference in level of the two leaf-traces. $\times 180$.

Fig. 5. Transverse section of basal region of young sporeling, showing the central cylinder only. Note the curious appearance of the reticulate tracheides in sectiou. $\times 320$.

Fig. 6. Tracheides from the basal region of the same sporeling more highly magnified. $\times 640$.

\section{PLATE VII.}

Fig. I. A node and part of an internode of a sporeling of $E$. arvense from a cleared preparation. Note the first development of metaxylem (M). $\times 425$.

Fig. 2. Base of a sporeling of $E$. arvense, showing two aerial axes and the early stages in the formation of the third. $\times 65$.

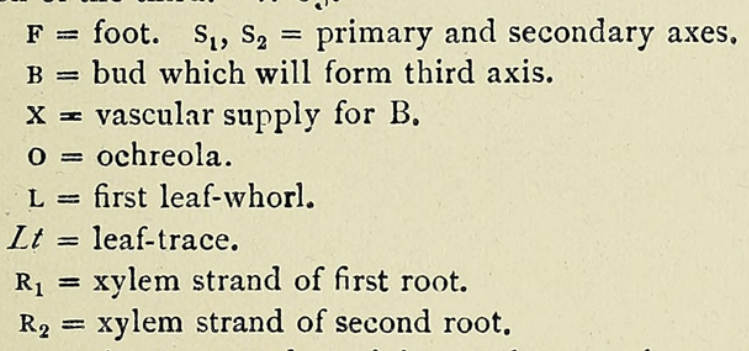

Fig. 3. A young node and internode near the apex of a sporeling of $E$. arvense before the nodal tracheides have linked up the internodal xylem. From a cleared preparation. $\times 425$.

Fig. 4. Four internodes of a bud of E. maximum, showing the early differentiation of internodal xylem. Note that the strict alternation of the strands is departed from by the introduction of an extra member in one whorl. From a cleared preparation.

Fig. 5. The vascular supply of half a cone of E. palustre. From a cleared preparation. $\times 12$. tion, $\times 12$. 
Annals of Botany,
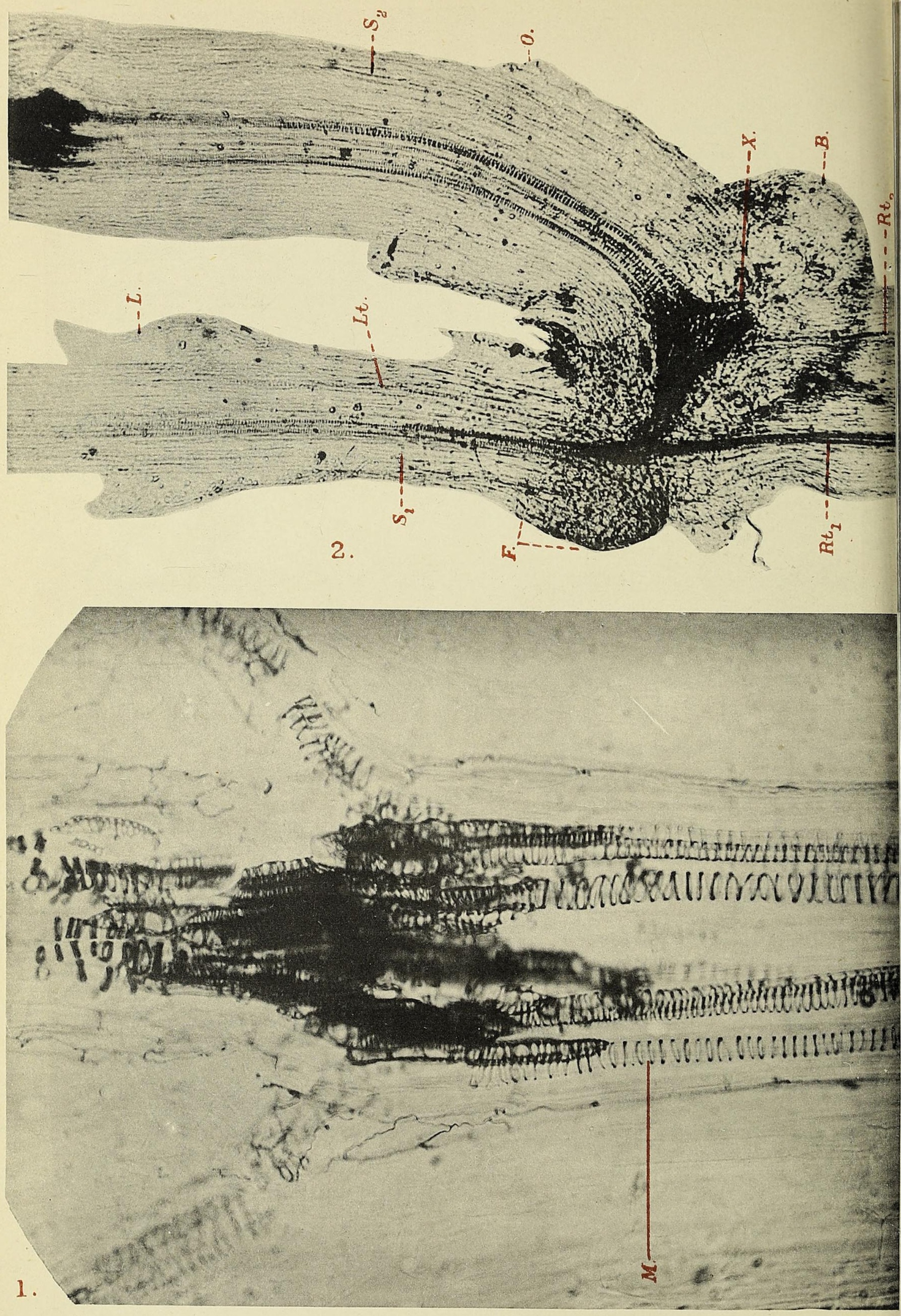

BARRATT-EQUISETUM. 


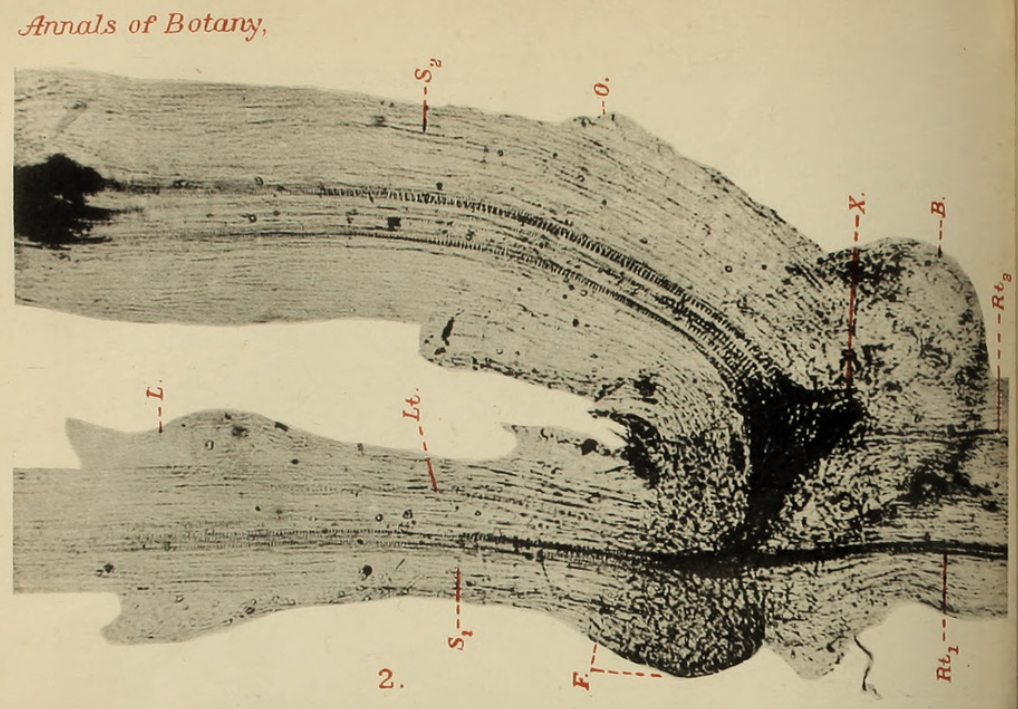

Vol. XXXIV, PL.VII.
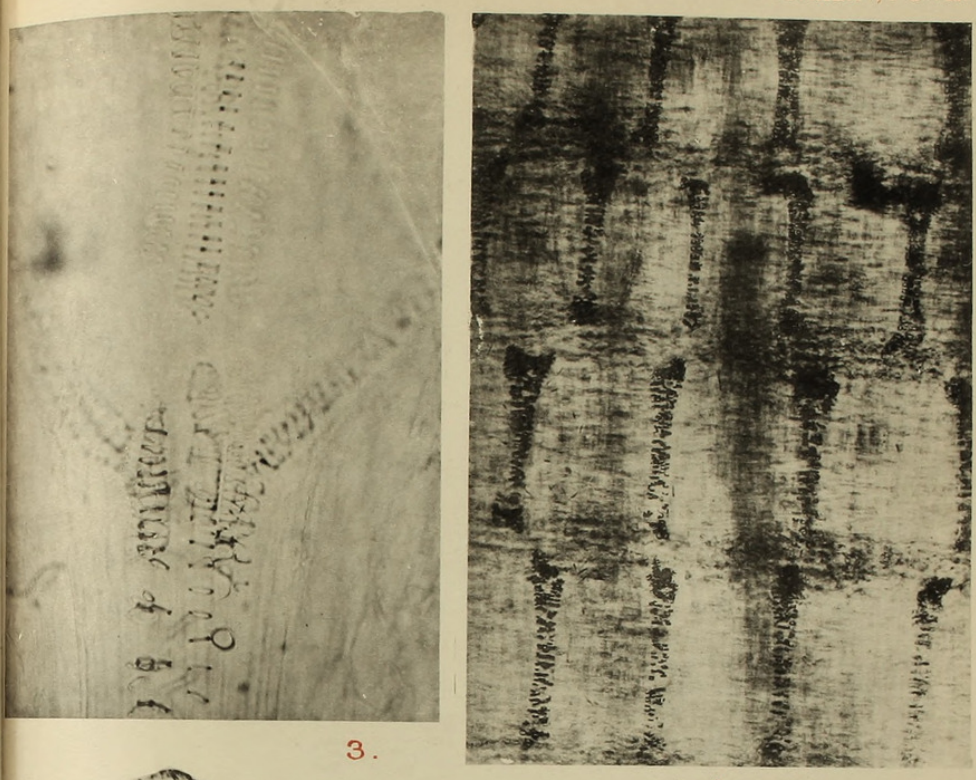

rese

3.

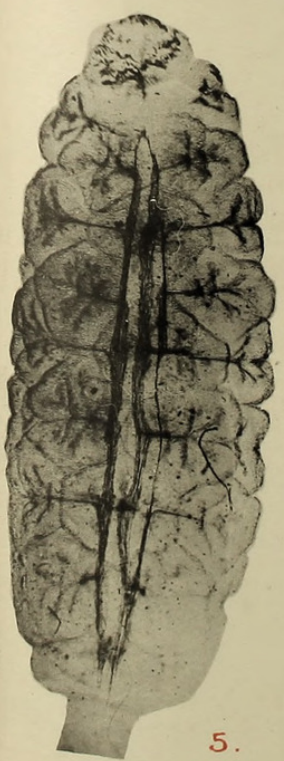

4

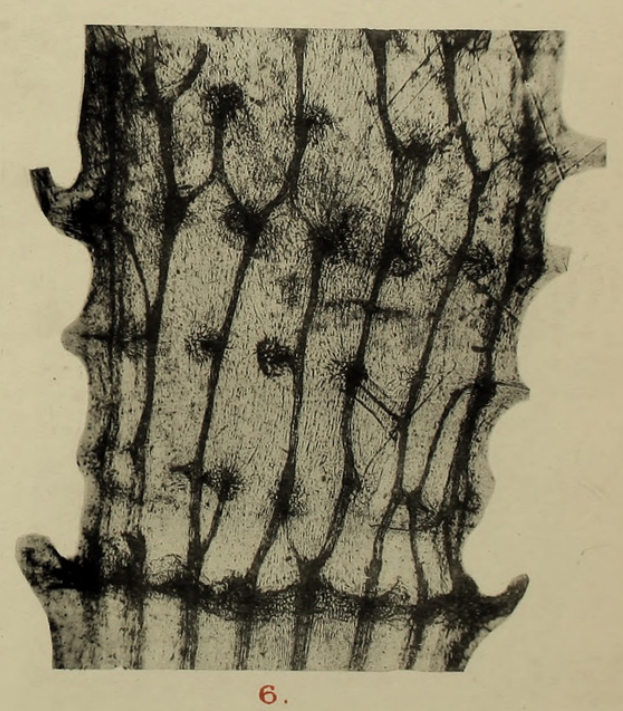


Annals of Botany
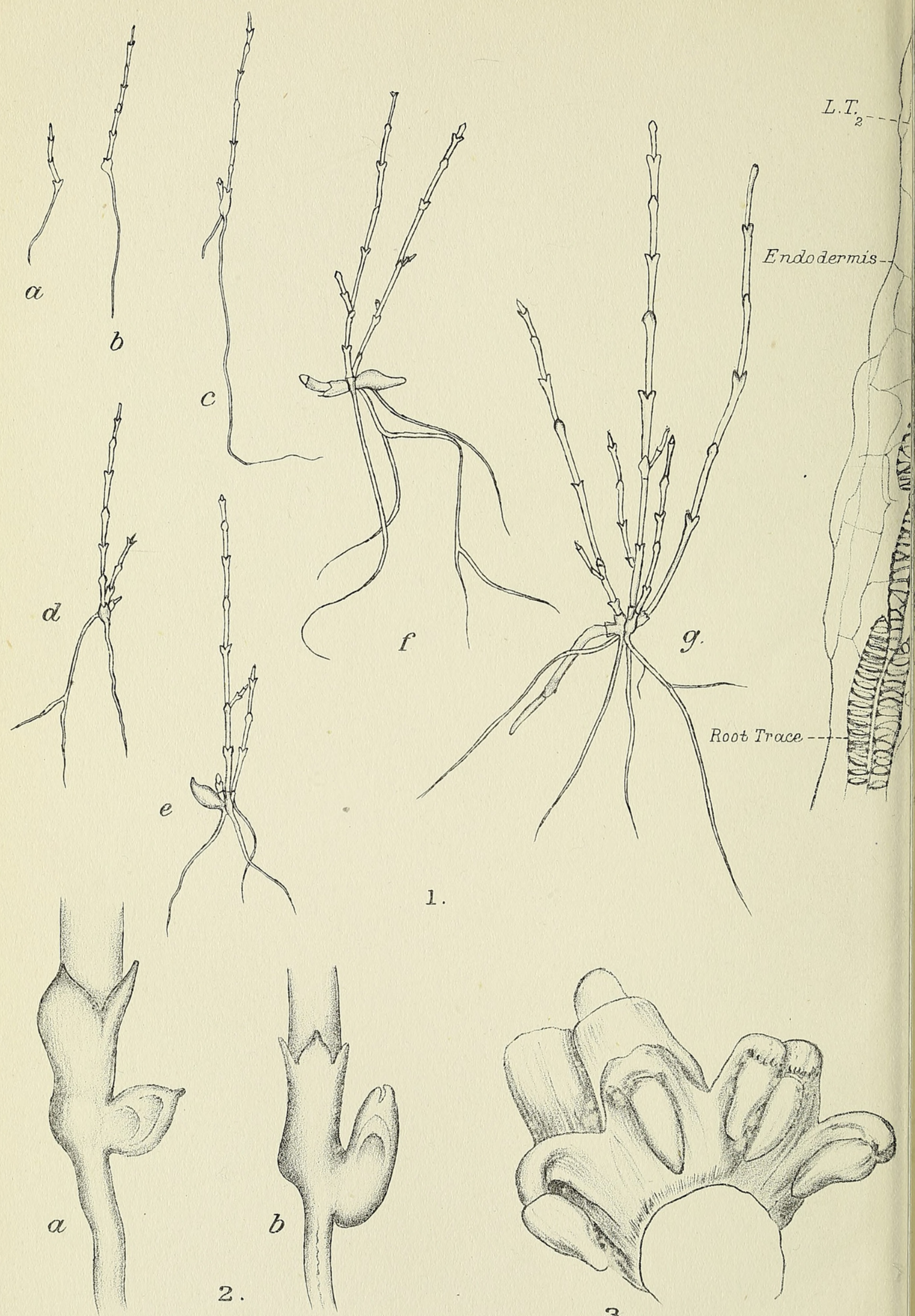

3. 


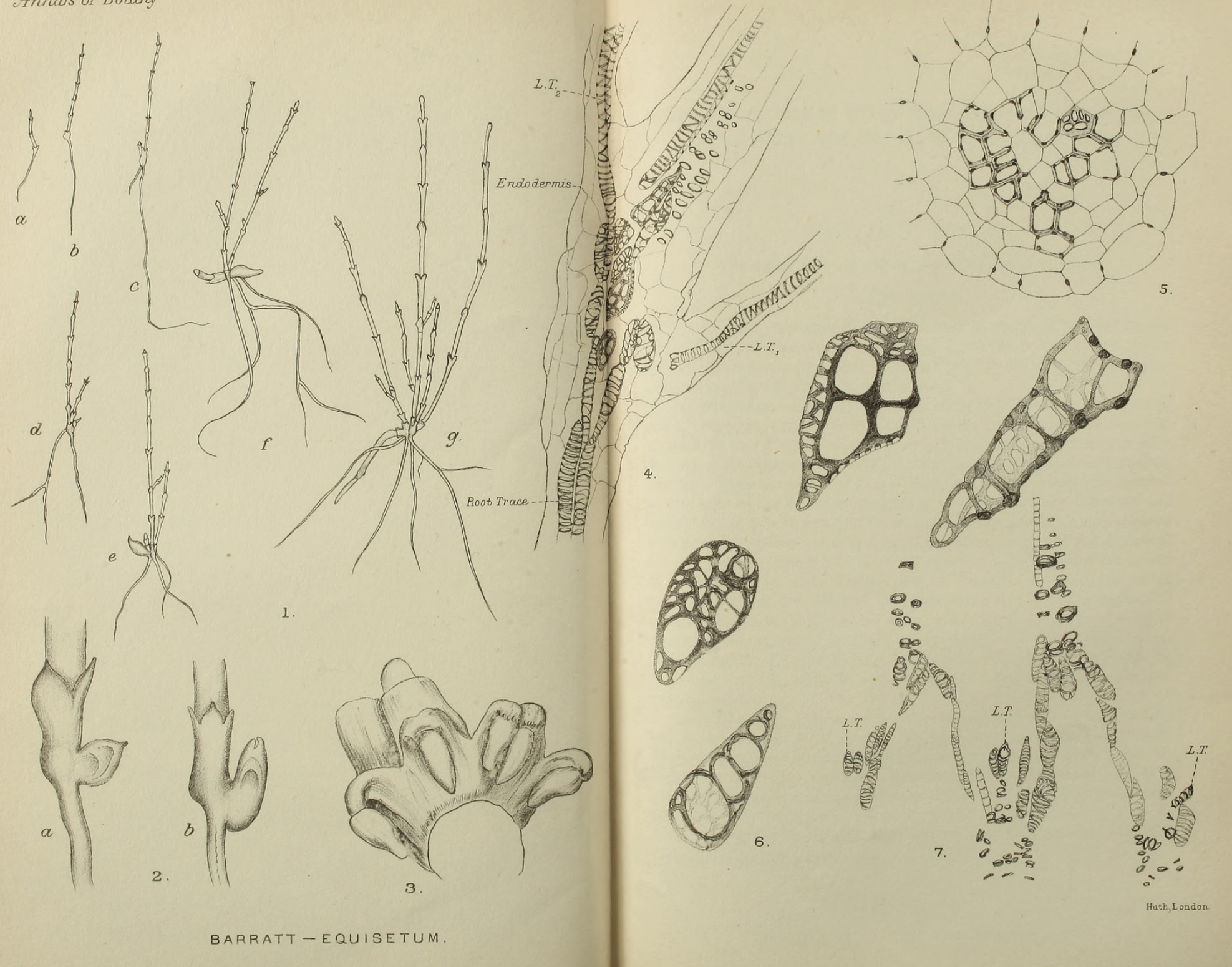




\section{$2 \mathrm{BHL}$ Biodiversity Heritage Library}

Barratt, Kate. 1920. "A contribution to our knowledge of the vascular system of the genus Equisetum." Annals of botany 34, 201-235.

https://doi.org/10.1093/aob/os-34.2.201.

View This Item Online: https://www.biodiversitylibrary.org/item/236972

DOI: https://doi.org/10.1093/aob/os-34.2.201

Permalink: https://www.biodiversitylibrary.org/partpdf/320285

\section{Holding Institution}

Smithsonian Libraries

\section{Sponsored by}

Biodiversity Heritage Library

\section{Copyright \& Reuse}

Copyright Status: Not in copyright. The BHL knows of no copyright restrictions on this item.

This document was created from content at the Biodiversity Heritage Library, the world's largest open access digital library for biodiversity literature and archives. Visit BHL at https://www.biodiversitylibrary.org. 